\title{
Ética na publicidade e propaganda: a visão do executivo de agências de comunicação do Rio Grande do Sul
}

\author{
Ethics in publicity and advertising: the vision of an advertising agency executive in Rio \\ Grande do Sul.
}

\author{
Aida Maria Lovison ${ }^{1}$ \\ Martin de La Martinière Petroll ${ }^{2}$
}

\begin{abstract}
Resumo
O marketing, enquanto área da Administração, inclui a propaganda, ferramenta que tem sido alvo de constantes questionamentos éticos de parte da sociedade. Apesar de existir no âmbito brasileiro e mundial um grande número de estudos focados nos efeitos da propaganda sobre o consumidor, o mesmo não pode ser dito quando se trata de analisar a relação entre ética e atuação das agências de comunicação e, por via midiática, com a sociedade em geral. Inserido nessa lacuna, o presente estudo visa elucidar quais valores estão subjacentes aos posicionamentos adotados pelos executivos de agências de comunicação situadas na Região Metropolitana de Porto Alegre/RS no que tange aos valores que fundam o vínculo entre agência, patrocinadores e a própria sociedade. Nesse intuito, foram realizadas entrevistas em profundidade com executivos de agências de comunicação; posteriormente, os textos foram transcritos e analisados através de mapas de associação de ideias. Como resultados, verificou-se a existência de certo "vazio ético". Assim, embora reconheçam a indissociabilidade entre vida ética no trabalho e na vida pessoal, há contradições. Não obstante, identificaram-se profissionais que, apesar das tensões advindas deste cenário, decidem corajosamente fazer valer posições que ratificam, mesmo em situações-limite, a impossibilidade de conceder face a um critério essencial para a ética: o respeito, principalmente, pela pessoa; isto é, a alteridade.
\end{abstract}

Palavras-chave: ética; propaganda; agência de comunicação.

Artigo submetido em maio de 2010 e aceito para publicação em outubro de 2010.

1 Doutora em Sociologia pela Université Paris VII; Professora adjunta da Universidade Federal do Rio Grande do Sul (UFRGS). Endereço: Escola de Administração/UFRGS, Rua Washington Luiz, 855, CEP 90010-460, Porto Alegre, RS, Brasil. E-mail: amlovison@ea.ufrgs.br

Doutorando em Administração pela Universidade Federal do Paraná (CEPPAD/UFPR). Endereço: Rua dos Eucaliptos, 552, CEP 88054-150, Florianópolis, SC, Brasil. E-mail: martin petroll@yahoo.com.br

Os autores agradecem à Gisele Dias, Bacharel em Administração pela UFRGS, por sua inestimável contribuição na consecução do estudo e aos revisores desta Revista pelas sugestões valiosas ao melhoramento do artigo. 


\begin{abstract}
Marketing, as a field of Administration, includes advertising, a tool that has been subject to constant ethical questions in society. Although there are a large number of studies worldwide and nationally that focus on the effects of advertising on the consumer, the same cannot be said when it comes to analyzing the relationship between ethics and communications agencies with society in general. Inserted into this gap, this study aims to elucidate which values are considered by executives when working at advertising agencies located in the metropolitan area of Porto Alegre/RS. We conducted interviews with executives, and data were analyzed through maps of association of ideas. Based on this systematic, a certain "ethical emptiness" was found. Thus, while recognizing the inseparability between life ethics at work and in personal life, some contradictions were found. Nevertheless, we identified professionals who, despite the tensions arising from this scenario, decide boldly to assert positions that ratify, even in extreme situations, not to give up and to bring to themselves a basic criterion for ethics: respect, especially to people, i.e., otherness.
\end{abstract}

Keywords: ethics; advertising; communication agency.

Introdução

O marketing surgiu nos primórdios da civilização ocidental, mas o seu conceito só foi estudado no início do século XX, com uma preocupação voltada ao processo econômico (BARTELS, 1974). Com o passar do tempo, novos conceitos foram sendo incorporados ao marketing, os quais, ampliando o seu escopo de atuação, o desvencilham de uma abordagem estritamente econômica que, finalmente, o impulsionam para um novo rumo: o da administração. Um exemplo dessa expansão são os "4 P's", desenvolvidos na década de 1950, e que incluíam atividades voltadas ao produto, preço, praça e promoção (BARTELS, 1974). Inserida nesta última está a propaganda e sua origem, a exemplo do marketing, remonta aos primórdios do processo de troca, desenvolvido e então praticado na forma oral, através de slogans orais (BOONE e KURTZ, 1998).

Com o respectivo desenvolvimento da imprensa no século XVIII e o surgimento das primeiras agências de publicidade e propaganda no século XIX, a propaganda se expandiu e tornou-se, nos dias atuais, numa das formas de arte mais prolíferas de todos os tempos (SIMPSON, HORTON e BROWN, 1996). Com efeito, hoje, tanto o marketing quanto a propaganda se apresentam como áreas organizacionais em constante transição (EL-ANSARY e KRAMER, 1973; CHURCHILL e PETER, 2000), alinhando-se, nesse processo, a mudanças em curso no âmbito da sociedade. Em virtude do exposto, a atividade de propaganda converte-se em um dos pilares centrais e, concomitantemente, a ferramenta de marketing mais visível e exposta ao público (D’ANGELO, 2003), tornando-se alvo de inúmeros estudos, bem como de questionamentos éticos de parte da sociedade, a quem decisivamente afere prestar serviço (NAIRN e BERTHON, 2003).

A despeito disso, existem poucos estudos sobre a relação entre escolhas éticas e atuação das agências de publicidade e propaganda, tanto no âmbito brasileiro quanto mundial (MAES, JEFFERY e SMITH, 1998; PETERSON, 2002; DRUMWRIGHT e MURPHY, 2004; PETROLL e LOVISON, 2005). Este é um fato que intriga, pois, no nosso meio, a veiculação de propagandas que transgridem as normas éticas do próprio Conselho Brasileiro de Autorregulamentação Publicitária (CONAR) é um fato corriqueiro.

Nesse sentido, recebem especial atenção as tensões e dificuldades de ordem ética tal como a vivenciam os executivos gaúchos das principais agências de comunicação no exercício de suas funções. Cientes de que se trata de uma atividade amalgamada no contexto da sociedade de mercado, o artigo busca identificar qual é a concepção ética ou o sistema de valoração do mundo que norteia, direciona a ação dos executivos que integram a pesquisa, no intuito de, segundo estes, fortalecer ou preservar a vinculação entre propaganda e ética. 
Os fundamentos teóricos do estudo centram-se, portanto, na busca de um aporte teórico sobre os dois temas centrais, ética e propaganda, ao qual sucede a justificação sobre os procedimentos metodológicos e de análise dos dados. Na culminância do texto, destaque para os achados do estudo e suas implicações para a Academia e para os agentes pesquisados, além das limitações do estudo e indicação de temas para investigações futuras.

\section{Fundamentos Teóricos}

Os fundamentos teóricos do estudo abordam, inicialmente, o problema da ética, onde se afirma que o fato dela estar indelevelmente marcada pelo sentido histórico da existência humana não impede, ao contrário, solicita uma reflexão rigorosa sobre algumas questões-chave: "o que é a ética para nós? Existe algum fundamento ou critério para julgar a minha a ação e a dos outros?" (RUIZ, 2004, p. 97). Já o segundo ponto contempla a propaganda, seu conceito, seus apelos e, finalmente, suas instâncias de (auto)regulamentação.

\section{Ética: Concepção e Valorações no Horizonte dos Sentidos}

O termo ética provém do vocábulo grego ethos, sinonímia de comportamento ou prática. Vinculada ao caráter da pessoa, isto é, ao senso moral e à consciência moral (CHAUI, 2004), "a ética mais do que um conceito definido, é um horizonte aberto e por isso o seu sentido é resignificado continuamente segundo as circunstâncias em que se desenvolvem as práticas humanas" (RUIZ, 2004, p. 96). Ou seja, tal como ocorre com os outros símbolos, não há uma definição fechada para o que seja a ética: a ética se exerce como prática e a cada prática surgem novas possibilidades de sentido porque as pessoas vivenciam de modo diverso a sua existência (RUIZ, 2004).

O vocábulo ethos em sua tradução latina significa morus, moral, costume, hábito. Ética e moral possuem essa raiz comum, e enquanto vocábulos são frequentemente encontrados juntos. Por manterem um vínculo lógico, a moralidade ou eticidade dos atos humanos é uma questão que pode ser estudada, segundo Freitag (2002, p. 13), valendo-se de uma pergunta aparentemente simples: "Como devo agir?", a qual, por sua vez, "é determinada com base na consideração de seu objeto, as circunstâncias e a finalidade". Portanto, para que um ato seja considerado moralmente bom, cada um destes elementos também deverá expressar essa mesma natureza. Em acréscimo, a moralidade de um ato pode, segundo Arruda, Whitaker e Ramos (2001), agravarse ou atenuar-se de acordo às circunstâncias. Neste caso, faz-se necessário considerar o ato como totalidade: o autor do ato, o local, o motivo, o fim, os meios utilizados e os resultados e consequências objetivas (SÁNCHEZ VÁZQUEZ, 2005). Assim como é impossível separar a dança, o ato de dançar e o/a dançante, no caso da ética, nem todos os meios são justificáveis, mas tão somente aqueles que são consoantes aos fins da própria ação, e este fim é o próprio homem, ou seja, a nossa humanidade. Portanto, "fins éticos exigem meios éticos" (CHAUI, 2004, p. 310).

Nota-se, nesse sentido, que houve a partir dos anos 50 uma significativa e crescente valorização do papel da ética nos negócios: primeiramente nos Estados Unidos e, depois, na Europa e no resto do mundo. Apesar de este movimento ter adquirido força a partir de alguns escândalos de corrupção (por exemplo, Watergate, Lockheed e Gulf Oil), a ética não se reduz à correção de fenômenos deste tipo, nem perde sua importância quando estes diminuem ou desaparecem.

Ora, o fato da ética estar indelevelmente marcada pelo sentido histórico da existência humana "não impede, ao contrário, solicita uma reflexão rigorosa sobre algumas questões-chave: o que é a ética para nós? Existe algum fundamento ou critério para julgar a minha a ação e a dos outros?” (RUIZ, 2004, p. 97). Há uma terceira, central para o estudo, que é a questão da ética como respeito à alteridade. Esta é a dimensão 
propriamente reflexiva onde o crescimento do sujeito, como pessoa dotada de liberdade, se dá a partir da relação que ele mantém com os outros sujeitos que também são livres (RUIZ, 2004).

O que se busca, com essa focalização, é encontrar meios que permitam depreender o sentido atribuído à ética pelos executivos que integram a pesquisa, o qual, segundo estes, serve de fundamento para decidir a respeito do que uma agência de publicidade e propaganda, por meio de sua atividade fim e em seu nome, pode aceita ou o que ele próprio se recusa a subscrever. Os códigos, a relação do sujeito com os valores e as normas, ou o agir por dever, e a alteridade como fundamento originário da relação humana constituem o conteúdo a seguir. 2

\section{A ética como código}

Assumir a perspectiva da ética como código consiste, primeiramente, em reconhecer que a ética, numa perspectiva histórica e prescritiva, "foi e é (ainda) compreendida como a compilação de princípios, valores e normas que os indivíduos têm que observar para manter uma conduta boa, decente, legal ou normal" (RUIZ, 2004, p. 97). O fato dos códigos definirem a priori o que os indivíduos devem fazer, como devem fazer e quando devem fazer caracteriza, segundo Sánchez Vázquez (2005, p. 72), "o nível da regulamentação moral consuetudinária [...] ou habitual do comportamento". No centro desta dinâmica está o costume, e sua qualidade moral reside no fato de que ele "opera como um meio eficaz de integrar o indivíduo na comunidade, de fortalecer a sua sociabilidade e de fazer com que certos atos contribuam para manter - e não desagregar - a ordem social" (SÁNCHEZ VÁZQUEZ, 2005, p. 72). O que dá significado moral ao caráter formal dos valores e preceitos é a convicção íntima - por indefinida ou obscura que seja - de que o que foi ontem deve ser hoje. Por essa razão, destaca Ruiz (2004, p. 97), "de algum modo, a ética do código disputa espaço de poder e saber com a normatividade positiva, isto é, com o direito legalmente promulgado".

Esse tipo de regulamentação moral, dominante nas sociedades tradicionais, onde o critério essencial da ética é a exterioridade, ou seja, "o prioritário é cumprir a formulação institucional dos princípios, normas e valores estabelecidos como bons e justos" (RUIZ, 2004, p. 98), independentemente de contexto, motivações ou opções, está, contudo, longe de ser superada. Há dois motivos fundamentais para isto, refere o autor. O primeiro motivo remete ao fato de que toda perspectiva ou formulação ética traz, de forma implícita ou explícita, algum tipo de normatividade, isto é, algum tipo de código sobre aquilo que considera melhor, correto, injusto, bom ou mau. É ingênuo, portanto, imaginar que a ética do código, onde a exterioridade é o critério ético por excelência, possa ser contornado ou superado pela mera consciência crítica da sua existência (RUIZ, 2004).

O segundo motivo encontra sua expressão nisto que o código oculta: a disputa de poder em torno à definição do que constitui a norma como o espaço da normalidade e seu desdobramento, a legalidade jurídica. Ora, explica Ruiz (2004), a norma não apenas confere uma aparência de normalidade e legalidade formal àquilo e àqueles que se ajustam a seu ditado: mesmo farisaico, o ajustamento estrito à norma reforça a aceitação social da instituição, das práticas ou dos valores. A detenção dos dispositivos de produção da ética, à luz dos quais uma sociedade define o que considera normativamente aceitável ou reprovável, indubitavelmente outorga o poder aos formuladores de constituir a norma como o espaço da normalidade e seu desdobramento, a legalidade. Afirmar que "a ética como código é dificilmente superável [diz, portanto, respeito] ao impacto que a norma tem, em qualquer sociedade, na legitimação de condutas e na normatização de comportamentos". (RUIZ, 2004, p. 99). Assim sendo, a ética se funde com o código, o qual opera como uma metonímia: "o modo formal da norma se transforma na forma normal de ser ético" (RUIZ, 2004, p. 98). No sentido exposto, uma codificação bem elaborada constitui o essencial da ética já que esta define o que é o bom comportamento, entendido, por sua vez, como a observância, mesmo reduzida a uma experiência farisaica, da norma dada. 
Hoje assistimos a uma difusão, quase indiscriminada, de códigos de ética. Estes códigos, sejam profissionais ou institucionais, prescrevem o que os indivíduos desse coletivo devem ou não fazer, o que lhes é permitido ou não no âmbito da sua prática. No mundo corporativo, foco deste estudo,

desde a série de escândalos desencadeada pelas fraudes contábeis que abalaram a economia americana [em 2002], um clamor moralizante atingiu os negócios. Nesse contexto, a ética definida como transparência nas relações e preocupação com o impacto de suas atividades na sociedade - vem sendo vista como uma espécie de requisito para a sobrevivência das empresas: ninguém quer ter o destino de uma Enron ou de uma WorldCom, empurradas para a concordata ou, o que é pior, de uma Arthur Andersen, varrida do mapa, [...] (REVISTA EXAME, 2003, p. 35).

Entretanto, em muitos casos, quando uma empresa oferece a seus funcionários e clientes um código de ética interno, o efeito perseguido nem sempre é o de orientar eticamente as suas práticas, mas dar uma garantia de que as suas atividades são eticamente irreprocháveis. O objetivo, em essência, é provocar a aceitação social dessas práticas que são apresentadas como éticas.

Para Ruiz (2004, p. 101), "a ética como código será um campo de poder", e o indivíduo que se enquadra nas normas desse código visto como normal, por se ater e ajustar o seu comportamento aos modelos sociais prescritos ou considerados socialmente relevantes. O efeito desse ajuste é a padronização dos comportamentos, o qual atende interesses, conforme já foi anteriormente referido, de quem detém o poder de definir a norma.

\section{A ética dos comportamentos}

A moralidade constitui, para Sánchez Vázquez (2005, p. 49; 52), o plano prático efetivo, ou a "moral em ação", isto é, "a moral prática e praticada". Embora moral (plano ideal, normativo ou prescritivo) e moralidade (plano prático, componente efetivo, real das relações humanas) sejam passíveis de uma distinção no plano referido, estão ambas integradas na conduta humana concreta. Assim, enquanto a moral designa "um conjunto de normas, aceitas livre e conscientemente, que regulam o comportamento individual e social dos homens em sociedade, a 'moralidade' é um tipo específico de comportamento dos homens ou de atos concretos que adquirem um significado moral com respeito à moral vigente" (SÁNCHEZ VÁZQUEZ, 2005, p. 66). Isso permite depreender o caráter determinante das pressões sociais no sentido de inculcar certas regras e preceitos e remete, sem dúvida, a uma perspectiva importante para a ética, que é a formulação e definição das práticas através dos códigos.

O que está no foco da perspectiva da ética dos comportamentos não é o estudo dos códigos definidos, mas compreender e definir de que forma o sujeito se apropria da norma. Esta é uma preocupação típica das abordagens deontológica e utilitarista da ética. A preocupação, nestes casos, explica Ruiz (2004, p. 103), é "em como um indivíduo deve praticar a honestidade, viver a sinceridade, ser justo, etc., em relação a uns princípios éticos ou a um código estabelecido".

Nesta perspectiva ética, há dois pólos nitidamente definidos: a pessoa, vista como uma essência naturalmente definida, e o código moral, algo conceitualmente definido ainda que num código de mínimos. E aqui está a pretensão ou a tarefa da ética dos comportamentos: realizar esta conexão entre os a priori da natureza humana com os valores efetivos da prática concreta dos indivíduos, em suma, "singularizar com eficiência os universais éticos" (RUIZ, 2004, p. 104). O objetivo de evitar o conflito, colocando, por antecipação, nas mãos dos agentes morais, com base no estudo de uma multitude de casos, uma regra de realização como base para uma decisão segura, é uma pretensão do casuísmo ou da casuística, 
se nos apresenta como um vão esforço, porque a singularidade e imprevisibilidade de cada situação real integram o ato moral num contexto particular que impede de ditar por antecipação uma regra de realização, coisa que não significa que não deva conformar-se necessariamente com certa norma moral de caráter geral (SÁNCHEZ VÁZQUEZ, 2005, p. $82)$.

Definir com antecipação a regra sobre "como devo agir" diante das situações leva a um empobrecimento da vida moral, lembra Sánchez Vázquez (2005), pois reduz a responsabilidade pessoal do sujeito na tomada de decisão e na escolha dos meios adequados para a consecução do fim almejado (SÁNCHEZ VÁZQUEZ, 2005).

Os elementos aqui expostos recolocam a necessidade de pensarmos no pluralismo ético e na historicidade dos valores sem cairmos na homogeneização nem no relativismo, já que isto significaria a diluição do sujeito. O questionamento recai, então, sobre qual critério comum pode ser então observado na tentativa de definir o que é correto, bom e justo? E é isto que enuncia o item a seguir.

\section{A ética como lócus da alteridade}

A ética como prática que constrói a subjetividade abrange tanto a forma singular e pessoal de vivenciar os valores, quanto a possibilidade do código (ética do código), bem como a da relação da pessoa com o código (ética dos comportamentos). Há uma outra perspectiva, porém, marginal e hoje quase em desuso, embora pertença à tradição filosófica: "a ética como prática que constrói a subjetividade" (RUIZ, 2004, p. 105). Desse ponto de vista, a constituição do sujeito se faz através da prática ética, e esta prática não só possui uma relação de exterioridade a respeito de um código; ela tem implicação na forma de ser do próprio sujeito. Sob esta égide, "a ética é a potencialidade ou o desafio que cada pessoa tem e enfrenta de poder, através da prática vivenciada de valores e formas de existência, se constituir como sujeito" (RUIZ, 2004, p. 105). Esta perspectiva da ética como prática de subjetivação é, para nossa contemporaneidade, a que merece maior reflexão. Ou seja, há uma afirmação da singularidade de cada sujeito, sendo este reconhecido como alguém que se cria e se constitui de forma única e irrepetível pela interação criativa com o mundo. Nesta recriação, entretanto, o mundo e as circunstâncias existem de forma concreta e, nele, valor e sentido se imbricam, de tal modo que, nós todos, ao valorar (res)sentimos a nossa existência e o mundo em que atuamos.

Existe uma alteridade do mundo que não é redutível ao sentido, mas essa alteridade não existe para nós fora do sentido. A alteridade condiciona a nossa prática valorativa, não podemos transpor a alteridade de forma absoluta pois nesse caso fabricaríamos não só um mundo de sentidos, mas de ficções (RUIZ, 2004, p. 116).

No horizonte da prática e da valoração humanas, a ética não se reduz, portanto, a uma teoria nem a uma lógica que confere universalidade à ética: é através da prática ética que a subjetividade se constitui. Todavia, a prática ética como a dimensão constitutiva da subjetividade que implica e direciona os demais saberes e práticas humanas apontam para uma teleologia da existência, não como algo pré-definido, mas como uma opção existencial por um estilo de vida ou existência bela, o modo estético de existência assim denominado pelos clássicos. Ora, a relação entre ética e subjetividade passava, na experiência greco-romana, "por dois elementos principais que eles denominavam de cuidado de si e de prática da virtude" (RUIZ, 2004, p. 122).

Eis porque, segundo Aristóteles, é preciso que o homem, o ouvinte [jovem], "tenha sido educado em hábitos honestos" (FONSECA, 2003, p. 28). E para expressar a posição daquele que não os tem e nem cuida de os adquirir, Aristóteles invoca Hesíodo: "Ótimo é aquele que por si tudo entenda; sábio é também aquele que obediente ouça quem bem fala; mas quem por si não pense nem ouvindo a outrem sinta o coração desperto, este é, em verdade, um homem inútil" (FONSECA, 2003, p. 28). 
Este modo de ser supõe, com efeito, a capacidade de ouvir falar de honestidade, de justiça, como também de coisas políticas. Para Aristóteles, não obstante, "o ser virtuoso, visto como mera qualidade, é repudiado como inútil: o importante é agir virtuosamente" (FONSECA, 2003, p. 29). O escopo da ética, segundo esta filosofia, não é o convencer, a argumentação retórica, porém o fazer. Com efeito, se alguém for educado nos princípios morais, não lhe será difícil, posto que o reconhece, aprender também a ciência da moral (Ética).

Este dilema contemporâneo sobre os modos de subjetivação, fulcro da filosofia política clássica, é, no entender de Ruiz (2004), uma questão chave para entender as tendências e fenômenos atuais, posto que situa tal problemática face a dois horizontes (paradigmas) divergentes: a) como subjetivação autônoma, b) como sujeição do indivíduo. No horizonte da sujeição, o indivíduo moderno é submetido a uma imensa variedade de mecanismos e tecnologias, os quais não se impõem pela força autoritária da coação, mas por dispositivos de poder que o induzem pela fabricação da sua subjetividade. Identificar o tirano - "e há três tipos de tiranos, os que recebem o reino por meio do voto dos eleitores; os outros através do poder das armas; os últimos por sucessão de sua raça" - é, para Étienne de la Boétie [1548] (2006, p. 35), "[...] a condição para agir com liberdade". Ser livre supõe educar-se para tal, ou seja, cada um tem que conquistar a capacidade de construir a própria maneira de ser livre.

A valoração como forma de simbolizar (instituir sentido) à existência é, portanto, uma forma de simbolizar a própria prática, e "a ética, entendida como prática valorativa, é a dimensão constitutiva da subjetividade que implica e direciona [os demais] saberes e [...] práticas humanas" (RUIZ, 2004, p. 119). Existe, portanto, "uma dimensão reflexiva da ética" (RUIZ, 2004, p. 119) e esta forma simbólica da liberdade a que esta reflexividade da vida ética se vincula não coincide com a perspectiva liberal de liberdade que predominou nas sociedades contemporâneas, que vincula a liberdade com a falta de obstáculos externos. Segundo essa tendência naturalista de liberdade, "um indivíduo é totalmente livre quando consegue levar a efeito tudo o que deseja” (RUIZ, 2004, p. 129).

Para o autor, esta visão de liberdade é o sustentáculo da sociedade de consumo, visão que, segundo ele, perpassa uma constelação de instituições cujo mote consiste em fabricar subjetividades flexibilizadas através da produção e o estímulo permanente dos desejos do indivíduo. É forma simbólica de liberdade onde a minha liberdade tem como limite a liberdade do outro perpassa, também, uma grande parte do aparato jurídico e político das sociedades atuais, sendo bons exemplos, questões relativas aos direitos de propriedade, aos códigos de conduta, ao sentido do lucro e às formas políticas de relações na produção.

Anota Phillips (1997, p. 113) que "o capitalismo econômico, com sua ênfase na acumulação, faz desta atividade um fim em si mesmo" exigindo que um "vasto número de mercadorias diversas sejam produzidas e vendidas". Ora, quando a autora discute os amplos efeitos sociais do capitalismo e sua influência no crescimento do materialismo em nossa sociedade, ela também se pergunta sobre os efeitos sociais da propaganda, já que "ela é uma ferramenta que o capitalismo usa para alcançar os seus objetivos" (PHILLIPS, 1997, p. 115). O fato de rebater a afirmação corrente de que, na origem dos efeitos sociais negativos da "ética do consumo", está a propaganda, e não o sistema capitalista, não a impede de reconhecer que

ao direcionar a atenção dos consumidores para o consumo, a propaganda pode contribuir para negligenciar outros valores sociais considerados importantes pela família, governo, ou instituições religiosas. [...] Esse ciclo de consumo é necessário porque a estabilidade e a autoridade da nossa sociedade [...] está fundamentada nas realizações da produção econômica (PHILLIPS, 1997, p. 113).

Então, é necessário retornar à ética da alteridade como filosofia primeira e novamente perguntar: desde qual outro neste setor de atividade as perguntas são formuladas, e a partir de qual outro os envolvidos justificam o seu agir?

A forma de subjetivação autônoma traz portanto para o horizonte da existência, não apenas a força singular, criativa do sujeito e sua responsabilidade por constituir a sua subjetividade; porquanto, "ao contrário do 
ditado popular, a minha liberdade não termina onde começa a do outro, senão que a minha liberdade se expande com a liberdade do outro" (RUIZ, 2004, p. 151). Noutros termos, a interação com o outro, também sujeito constituído de forma livre e autônoma, me ajuda a crescer na minha autonomia, permitindo ao eu orientar-se para novos horizontes de ser. Por ética, desse ponto de vista, entende-se, em essência, "a construção do sentido da vida humana desde o encontro com o outro" (SOUZA, 2004, p. 56).

A alteridade, como fundamento originário da relação humana, é, assim, o critério ético a partir do qual deve pautar-se toda prática humana. "Este dever se constitui como tal pelo fato de que a alteridade é um referente intransponível além do qual só existe a (auto)destruição do mundo, da vida, do outro e como consequência o aniquilamento paulatino do sujeito" (RUIZ, 2004, p. 152). Esta interlocução a partir do critério ético da alteridade é imprescindível para que a prática do sujeito e da sociedade se efetive como relação intersubjetiva com o outro e interativa com o mundo no horizonte de uma nova significação existencial para a própria subjetividade. Sob esta referência, e num horizonte de pluralidade possível, o sujeito deve construir seu estilo de vida e os valores respectivos em suma.

A alteridade, perpassando todas as práticas humanas, incluso as formas de tecnologia e os modos de produção, serve como referência para relativizar o relativismo ao afirmar a pluralidade das práticas éticas de subjetivação e os modos culturais sobre como essas práticas podem se dar; "porque qualquer prática humana tem como limite a dignidade do outro, o respeito pela vida e a preservação do mundo" (RUIZ, 2004, p. 154). A transgressão desses limites leva à exclusão cultural e econômica, trazendo o risco de encaixar o outro nos moldes da nossa medíocre percepção.

Ora, em tempos de crise o que aparece, em lugar do fortalecimento da democracia, o único regime capaz de criar as condições necessárias para que a pessoa humana realize a sua dignidade (DI LORENZO, 2010), é "uma destruição do tecido cívico, [que] é justamente o resultado da centralidade do consumo" (BARBER, 2010, p. 1). Deste modo, "[...] o sujeito, ao ter que escolher, não desfruta positivamente da sua liberdade, mas padece a condição dolorosa de ter de efetuar uma escolha na qual, ao abraçar um valor, estará repudiando outro" (SILVA, 2010, p. 49). Ensina Aristóteles (2001) que o bem é algo desejado per si e não em razão de outro. Bem para ele é aquilo a que todas as coisas tendem, e o bem propriamente humano é o fim. Este fim se realiza no tempo e no espaço, e sua realização depende de fins intermediários, podendo ser definidos como meios, ou bens contingentes. Se assim for, não é a alteridade, num horizonte de pluralidade, o critério ético comum a ser observado sem concessão na tentativa de definir o que é correto, bom e justo?

Porém, ao se refletir sobre ética e situações-limite, é importante compreender que nas esferas de valores que orientam a conduta humana (moral, religião, mitos, conhecimento, tradição, política, família, etc.), não existe uma sucessão histórica vinculada a etapas em possível evolução, mas uma situação de tensão em que tais esferas convivem como apelos permanentes e respostas possíveis à pergunta ética, fulcro da moralidade: $O$ que devo fazer? Como devo agir? (FREITAG, 2002; SILVA, 2010). Em determinadas circunstâncias, pode ocorrer a prevalência de certos critérios, que aparecem, então, como os mais relevantes para a tomada de decisões éticas. Assim, uma posição incômoda ou angustiante se manifesta no plano singular do sujeito que age: o fato de se deparar com duas exigências de compromisso obriga "o próprio sujeito a ter de responsabilizar-se por conferir a uma delas o caráter de imposição absoluta" (SILVA, 2010, p. 49). Face ao "dilema da ação em um mundo de indiferença e cinismo" (BREGANTINI, 2010, p. 46), é importante compreender então que, "no plano ético, não há incompatibilidade entre o bem individual e o bem comum. [...] Sem o bem comum [que é o fim da vida social materializada nos bens fundamentais], a plenitude humana tornar-se-ia uma fábula, uma utopia", confere Di Lorenzo (2010, p. 26).

\section{Propaganda: Conceito, Apelos e Instâncias de (Auto)Regulamentação}

A propaganda é um dos pilares do marketing (D’ANGELO, 2003) e encontra-se inserida neste, através do conceito da promoção, um dos "4 P's" do mix de marketing. Todavia e de acordo com Shimp (2002, p. 31), o 
termo promoção será aqui substituído por comunicação de marketing, já que este último "é hoje preferido pela maioria dos profissionais de marketing e pelos professores [da área]". Dessa forma, a atividade de comunicação de marketing representa "o conjunto de todos os elementos no mix de marketing de uma organização, os quais facilitam o intercâmbio, estabelecendo significado compartilhado com os clientes da organização" (SHIMP, 2002, p. 511).

O significado da palavra propaganda, todavia provém do gerúndio do latim propagatio, de propagare, significando multiplicar, estender, propagar [a fé] (RABAÇA e BARBOSA, 1987; DICTIONNAIRE LE PETIT ROBERT, 1993). Ou seja, refere-se a qualquer forma de comunicação em caráter não pessoal paga por um patrocinador identificado sobre um bem tangível, intangível ou para campanhas de mudança de comportamentos e ideias (KAMLOT e ROCHA, 2001; REICHERT, 2002). Churchill e Peter (2000) afirmam em complementação ao conceito acima, que a propaganda concerne um anúncio ou mensagem persuasiva, buscando informar ou persuadir integrantes de uma audiência específica (BOONE e KURTZ, 1998; SHIMP, 2002).

O Código de Ética dos Profissionais da Propaganda, desenvolvido em outubro de 1957 é mais sucinto, porém não menos importante e conceitua a propaganda, no item 1, como sendo "a técnica de criar opinião pública favorável a um determinado produto, serviço, instituição ou ideia, visando a orientar o comportamento humano das massas num determinado sentido".

A propaganda trata, assim, de um tipo de demanda centrado nos interesses de empresas, organizações, pessoas e de agências governamentais, as quais se utilizam deste meio para informar e persuadir o públicoalvo acerca de determinado produto (entenda-se, variedade de bens e serviços). Ratifica-se, sob esta égide, a importância atribuída à comunicação persuasiva (BOONE e KURTZ, 1998; SHIMP, 2002), em virtude de sua função: informar aos clientes potenciais sobre as virtudes dos produtos, visando persuadi-los ou lembrálos para que os consumam. A propaganda pode igualmente transmitir informações acerca das organizações, com a vantagem de poderem informar, a um só tempo, um grande número de clientes (CHURCHILL e PETER, 2000).

É importante salientar que a propaganda terá eficácia se houver um entendimento dos componentes desse processo por parte dos atores envolvidos, que se inicia com uma fonte de emissão formal (organizações que visam ou não o lucro) ou informal (parentes, amigos, entre outros), onde a mensagem (propaganda) será transportada, através de um canal de transmissão (televisão, revista, jornal, Internet, etc.), até um ponto de recepção, ou seja, até o público a quem se destina a mensagem (CHURCHILL e PETER, 2000; SCHWEIG, 2002).

Para tanto, surge o papel da agência de propagada, assim delimitado no Regulamento Brasileiro do Decreto n 57.690 (capítulo 1 , seção $1^{\text {a }}$, art. $6^{\circ}$ ), de fevereiro de 1966 :

A pessoa jurídica especializada nos métodos, na arte e na técnica publicitários, que, através de profissionais a seu serviço, estuda, concebe, executa e distribui propaganda aos Veículos de Divulgação, por ordem e conta de clientes anunciantes, com o objetivo de promover a venda de mercadorias, produtos e serviços, difundir ideias ou informar o público a respeito de organizações ou instituições a que servem.

Seu objetivo, portanto, é criar uma conscientização e fornecer informações sobre a marca para uma audiência cuidadosamente selecionada, reforçando ou mesmo modificando atitudes, percepções, crenças e o comportamento do consumidor perante a marca do produto anunciado, além de outras questões (REICHERT, 2002). Essas informações estão contidas na mensagem criada pela agência de propaganda e se destinam ao receptor para que este as absorva e aja no sentido comportamental visado.

Com efeito, refere Chandy et al. (2001), as agências de propaganda inserem diversos apelos na propaganda, os quais podem ser perscrutados com base em quatro categorias: forma, proeminência, estrutura e fonte. A 
forma do apelo é o critério que permite aos idealizadores inicialmente avaliar a conveniência do uso de emoções ou de argumentos em cada situação específica.

Visando objetivamente mensurar, desse ponto de vista e através de pesquisa as emoções nos comerciais, Chandy et al. (2001) contabilizaram o número de benefícios emocionais mencionados pelos respondentes do seu estudo, classificando os apelos emocionais em quatro tipos: amor (por exemplo, com transmissão de acalento - warmth, cuidado em relação às pessoas queridas); orgulho (em ser responsável, em ter feições bonitas, filhos bonitos, entre outros); culpa (entre outros, por não ser bom, respeitoso); e, por último, medo (das consequências por não utilizar o produto anunciado). A contabilização do número de benefícios factuais (baseados em informação recebida) foi diferenciada enquanto: i) apelos de refutação - ao apresentar determinada premissa e, na sequência, contrapô-la com evidências ou ideias contrárias; ii) apelos de comparação - ao comparar o produto ou serviço anunciado com outro; e iii) posicionamento único, manifestando uma tentativa de mudar (para acolhimento mais favorável) o critério de avaliação dos consumidores a respeito do objeto do anúncio.

A proeminência do apelo é o critério relacionado com fatores destinados a colocar em evidência questõeschave concernentes aos produtos ou serviços, como tamanho (utilizando, por exemplo, letras grandes ou letras pequenas na mensagem), duração (relativa ao tempo em que um anúncio fica exposto na tela) ou o número de vezes em que a peça publicitária é veiculada. Por sua vez, a categoria estrutura do apelo concerne os modos de apresentar os usos possíveis de um dado produto: de uma maneira positiva, destacando seu potencial para gerar benefícios e ganhos, ou a partir de um enfoque negativo, ou seja, dando ênfase ao seu potencial para evitar perdas ou resolver problemas.

A fonte do apelo, por fim, diz respeito aos endossantes, isto é, pessoas especialistas, cujo conhecimento ou experiência relacionada ao produto proporciona certa autoridade para apresentar seus atributos e benefícios, podendo, assim, exercer alguma influência sobre os consumidores. Cabe mencionar, neste caso, o importante papel das celebridades, sejam elas artistas, atletas, entre outros, mesmo quando desprovidas de expertise sobre o objeto anunciado (SHIMP, 2002). Dada a frequência com que vem sendo utilizado, muitos estudos já foram realizados visando examinar as respostas dos consumidores quando expostos a esse recurso. Os resultados demonstram que o endosso de pessoas famosas contribui para o recall da mensagem publicitária, para a credibilidade do anúncio e para criar uma peculiar personalidade para a marca (AGRAWAL e KAMAKURA, 1995).

A partir da mencionada estrutura, poder-se-ia incluir outras formas de apelo não levadas em conta pelos autores em referência, mas cujo indicativo está presente na literatura sobre o tema: apelo à música (BRUNER, 1990; KELLARIS, COX e COX, 1993), a o humor (ALDEN, HOYER e LEE, 1993), ao sexo (LATOUR e HENTHORNE, 1994; HENTHORNE e LATOUR, 1995; PETROLL e ROSSI, 2008); às causas sociais (DRUMWRIGHT, 1996; BRUNEL e NELSON, 2000) e às causas ambientais (SCHUHWERK e LEFKOFF-HAGIUS, 1995; NEWELL, GOLDSMITH e BANZHAF, 1998).

Face ao caráter instrumental da propaganda, parece evidente e simultaneamente compreensível que ela não seja classificada em si e a priori como sendo boa ou má. Ela pode, contudo, enquanto mecanismo de persuasão, orientar o seu esforço para qualificar o processo de comunicação, buscando fundamentos numa ética do respeito a todo o ser (JONAS, 1995), evitando estimular o consumismo exacerbado e reconhecidamente expresso na "metáfora do consumidor" (HUTTON, 2005). Para o autor, esta ênfase consiste em ajudar as pessoas a obterem o que elas querem e não o que elas precisam, usurpando a responsabilidade moral da instituição, esteja ela voltada à educação, religião, comunicação, ciência ou à saúde.

A suspeição face aos conteúdos da propaganda não decorre, portanto, do fato desta primordialmente constituir-se em um instrumento eficaz na divulgação de informações concernentes a um determinado produto ou serviço, mas do tipo de ideias que uma determinada peça publicitária por vezes subliminarmente veicula. Quer dizer, o problema não está diretamente referido ao uso da propaganda como instrumento de comunicação, mas no conteúdo persuasivo, recorrente e muitas vezes questionável de suas mensagens. Não 
sem razão, há um cuidado especial por parte dos órgãos de regulamentação, com tudo o que diz respeito a questões ligadas à raça, condição social, idade (por exemplo, em anúncios voltados às crianças) e apelos eróticos e violentos. Neste caso, incumbe àqueles e à própria sociedade fazer valer os princípios e direitos constitucionais e regimentais, preservando em nome da ética e da justiça, o direito do cidadão em obter informação protegida tão quanto possível de interesses espúrios, o que significa informação decente e qualificada.

Em tais circunstâncias, justifica-se, portanto, o convite feito pelo educador brasileiro Paulo Freire, no dia 30 de março de 1997, em entrevista concedida ao repórter William Wack na Globo News: "Há necessidade de eticizar o mundo. Nós transgredimos a ética. É preciso, [face à licenciosidade da lógica do mercado], trabalhar para reduzir a possibilidade de des-eticizar o mundo". E é nesse sentido que a figura do consumidor, agente central no universo do marketing, deixa de ser uma metáfora livre de consequências. Ao se referir ao que vem atualmente acontecendo na sociedade norte-americana, Hutton $(2005$, p. 2) declara: "como cidadãos, os americanos tinham direitos e responsabilidades; como consumidores, eles têm direitos, mas poucas, se têm, responsabilidades".

Nesse sentido, entidades voltadas à seara da propaganda e o próprio Governo apresentam formas que visam eticizar o entorno. Uma dessas entidades é o Conselho Brasileiro de Autorregulamentação Publicitária, também chamado de CONAR. Ele surgiu de "uma ameaça ao setor: no final dos anos de 1970, o Governo Federal pensava em sancionar uma lei criando uma espécie de censura prévia à propaganda" (CONAR, 2010). Em 1980, e almejando "zelar pela liberdade de expressão comercial e defender os interesses das partes envolvidas no mercado publicitário, inclusive os do consumidor" (CONAR, 2010), expoentes da publicidade brasileira criam o CONAR e, logo em seguida, o Código Brasileiro de Autorregulação Publicitária. Tal documento não tem força normativa; todavia e por ser fruto de consenso entre os profissionais da área, o código tem grande força e influência, estabelecendo finalmente, para os publicitários, um padrão ético que eles próprios desejam ver refletido nos seus trabalhos.

Além do Código Brasileiro de Autorregulação Publicitária, outros foram criados e também permeiam assuntos correlatos ao que está sendo exposto nesse trabalho. Há, por exemplo, os Decretos Lei $n^{\circ} 4680$, de 1965, e o da Lei $\mathrm{n}^{\circ}$ 57.690, de 1966, promulgados pelo Governo Federal do Brasil com o intuito de regrar o exercício da profissão de publicitário. Tais decretos foram levados em consideração, pelo CONAR, quando, em 1980, decidiu criar o seu Código Brasileiro de Autorregulação Publicitária.

Finalmente, há que por em destaque o Código de Defesa do Consumidor, criado em setembro de 1990 pelo Governo Federal do Brasil, já completando vinte anos na realização desta finalidade que é a de defender o consumidor frente aos fornecedores de bens e serviços no País. Em última instância, porém, todos os códigos e decretos acima devem submeter-se, ao que reza a Constituição da República Federativa do Brasil. Criada em 1988, assim se manifesta, em seu Art. $5^{\circ}$, sobre os direitos individuais ou de cidadania: "[t]odos são iguais perante a lei, sem distinção de qualquer natureza, garantindo-se aos brasileiros e aos estrangeiros residentes no País a inviolabilidade do direito à vida, à liberdade, à segurança e à privacidade [...]”.

Tendo ciência do papel respectivamente exercido pela propaganda e por quem a agencia, bem como dos instrumentos de regulação existentes no País, demarcando a necessidade, conforme reza o CONAR (2010) de, na atividade publicitária, "[...] assegurar uma atividade ética, honesta e afinada com os valores da sociedade brasileira", faz-se mister explicitar os procedimentos metodológicos adotados nessa pesquisa realizada com o intuito de verificar de que modo, na prática publicitária, em especial na propaganda, a ética se faz ou não presente.

\section{Procedimentos Metodológicos}

A realização desta pesquisa de natureza qualitativa encontra respaldo no construcionismo social, abordagem assim particularizada por Spink e Medrado (2004, p. 104): 
O desafio que [...] se coloca é o de, sem abandonar a objetividade, ressignificá-la como visibilidade, concebida como pressuposto básico da intersubjetividade. Estão imbricadas aí a explicitação do processo de interpretação - tomando-o como circular e inacabado -, assim como a compreensão da dialogia na dupla acepção de elemento básico da produção de sentidos no encontro entre entrevistador e a voz do entrevistado [...] e do sentido da interpretação no encontro entre pesquisador e seus pares.

Assim, objetivando explicitar as bases do posicionamento ético dos executivos das principais agências de publicidade e propaganda gaúchas, manifestas no modo como estes realizam a intermediação anunciantesociedade em geral, buscou-se um processo exploratório de interpretação dos sentidos, na perspectiva construcionista, por esta justamente ser a atividade-meio-fim da pesquisa (SPINK e MEDRADO, 2004; PINHEIRO, 2004). Dessa maneira, a abordagem foi posta em prática através de entrevistas associativas técnicas específicas de entrevista -, por considerar "as práticas discursivas como linguagem em ação" (SPINK e FREZZA, 2004, p. 45) em que se produzem sentidos e versões sobre o cotidiano. Aqui, "o processo de interpretação é concebido [...] como um processo de produção de sentidos", sendo esta a tarefa da pesquisa. Desse modo, o pesquisador está, durante todo o percurso da pesquisa, imerso no processo de interpretação das práticas discursivas, reconhecidas como práticas sociais constituídas pelos seguintes elementos: a dinâmica (enunciados), as formas (speech genres), e os conteúdos (repertórios interpretativos). Quanto a estes, eles são, afirmam os mesmos autores, histórica e culturalmente construídos.

Nessa pesquisa, o levantamento de dados empíricos efetuou-se através de entrevistas realizadas com executivos das maiores agências de publicidade e propaganda situadas na região metropolitana de Porto Alegre, Estado do Rio Grande do Sul (IBOPE, 2008). Essa valoração das agências reflete não somente o faturamento de cada uma em determinado ano, mas também o seu porte (número de funcionários), a quantidade e grandeza dos seus clientes e os prêmios alcançados desde o surgimento de cada agência gaúcha (M\&M Online, 2010 - seção Anuários).

Assim, foram entrevistados cinco profissionais (um por agência), alguns dos quais proprietários, outros ocupando cargos de direção no respectivo empreendimento. O primeiro contato com os entrevistados foi realizado através de ofício assinado pela autoridade máxima da instituição de ensino que abrigou a pesquisa e remetido por fax, seguido de mensagem, por via eletrônica (e-mail), ratificando o convite à participação nessa pesquisa. Após estas medidas, foi realizado um contato telefônico com cada um dos potenciais entrevistados, visando personalizar a sequência do processo. Houve ainda a preocupação de se fazer uma consulta prévia a profissionais no intuito de validar as indicações, tendo por base a influência e a representatividade das agências escolhidas na citada região.

No que tange ao número de executivos entrevistados no presente trabalho (um total de 5), ele pode, em primeira instância, ser considerado de alcance quantitativamente restrito. Todavia, tal abrangência se coaduna com o tipo de pesquisa adotado, ou seja, uma pesquisa exploratória de base qualitativa. Os profissionais e estudiosos do campo sabem, também, que há, neste universo, nacional ou internacional, poucas agências de publicidade e propaganda situadas em lugar de destaque. Desse modo, o número de entrevistas encontra respaldo não apenas no tipo de estudo; ele é igualmente representativo posto que abarca a totalidade das agências que, no espaço da pesquisa, ou seja, a Região Metropolitana de Porto Alegre/RS, ocupam a posição acima referida.

As entrevistas com os executivos foram realizadas de forma individualizada conformemente ao dia e à hora acordados, e tiveram uma duração aproximada de uma hora. Com a respectiva anuência, todas as entrevistas foram gravadas, medida que objetivou preservar a integridade e fidelidade ao discurso proferido pelos integrantes da pesquisa. Por questões de sigilo, os entrevistados foram orientados a solicitar a interrupção do registro, seja na forma gravada ou por escrito, caso tal incidência viesse a ocorrer, mas não houve nenhum registro desta ordem. Todas as entrevistas foram integralmente degravadas e os textos remetidos aos respectivos interessados para validação, mediante leitura crítica. Todos os textos retornaram sem quaisquer indicativos de ajuste, e é esta versão final que serviu de base para a elaboração dos mapas de associação de ideias, conforme apresentado abaixo. 
Nesta consecução, e tendo sempre em mente que "não são apenas os conteúdos que nos interessam [mas que] precisamos entender, também, o uso feito desses conteúdos" (SPINK e MEDRADO, 2004, p. 106), a etapa de análise realizou-se com suporte na técnica denominada mapas de associação de ideias. Conforme Spink e Medrado (2004, p. 107), "os mapas têm o objetivo de sistematizar o processo de análise das práticas discursivas em busca dos aspectos formais da construção linguística, dos repertórios utilizados nessa construção e da dialogia implícita na produção de sentidos". Para estes, os mapas são elementos de visualização que têm duplo objetivo: dar subsídios ao processo de interpretação e facilitar a comunicação dos passos subjacentes ao processo interpretativo. Trata-se de uma abordagem construcionista na qual a produção de sentidos se processa no contexto da ação social, pautada pela visão hermenêutica da produção de conhecimento. O que se busca é a identificação dos processos pelos quais as pessoas descrevem, explicam e/ou compreendem o mundo em que vivem, incluindo elas próprias. Assume-se, à luz do exposto, que o foco do construcionismo é a interanimação dialógica com o outro, esteja ele fisicamente presente ou não. A concretização desse processo está detalhada no item a seguir.

\section{Análise e Interpretação dos Dados}

Spink e Medrado (2004, p. 107) explicam que "a construção dos mapas inicia-se pela definição de categorias gerais, de natureza temática, que refletem sobretudo os objetivos da pesquisa". Com base nesse procedimento, o fluxo de associação de ideias constituiu um mapa demarcado por três categorias principais: a) a ética na vida pessoal e profissional; b) o anunciante, a agência de publicidade e propaganda e o consumidor/sociedade; e c) os instrumentos de regulamentação dessa atividade. Ou seja, depois de transcritas todas as entrevistas e com a ratificação do seu conteúdo pelos respectivos entrevistados, o fluxo das narrativas foi organizado com base nessas categorias iniciais. Nesse processo, o diálogo foi mantido intacto ${ }^{\mathrm{ii}}$, apenas sendo deslocado para as colunas previamente definidas em função dos objetivos da pesquisa (SPINK e MEDRADO, 2004).

Porém, "os mapas não são técnicas fechadas" (SPINK e MEDRADO, 2004, p. 107); ou seja, o processo de análise levou, em alguns casos, à redefinição das categorias iniciais, "gerando uma aproximação paulatina com os sentidos vistos como atividade-fim" (SPINK e MEDRADO, 2004, p. 107). A realização desses passos, tendo presente, mais uma vez, os objetivos do estudo, confirmou a centralidade das três categorias já enunciadas.

Antes, porém, de mostrar os mapas de associação de ideias, informa-se o perfil dos entrevistados:

Tabela 1

\section{Relação dos Entrevistados}

\begin{tabular}{|c|c|c|c|c|c|}
\hline Entrevistado & $\begin{array}{c}\text { Idade } \\
\text { (em } \\
\text { anos) }\end{array}$ & Gênero & $\begin{array}{c}\text { Sua Experiência } \\
\text { Profissional no } \\
\text { Mercado } \\
\text { Publicitário } \\
\text { (em anos) }\end{array}$ & $\begin{array}{c}\text { Tempo da } \\
\text { Agência no } \\
\text { Mercado } \\
\text { (em anos) }\end{array}$ & $\begin{array}{c}\text { Formação } \\
\text { (graduação) }\end{array}$ \\
\hline A & $50-60$ & Masculino & 36 & 34 & Relações Públicas \\
\hline B & $30-40$ & Feminino & 13 & 18 & $\begin{array}{c}\text { Publicidade e } \\
\text { Propaganda }\end{array}$ \\
\hline
\end{tabular}




\begin{tabular}{|c|c|c|c|c|c|}
\hline C & $50-60$ & Masculino & 24 & 36 & $\begin{array}{c}\text { Publicidade e } \\
\text { Propaganda }\end{array}$ \\
\hline D & $40-50$ & Masculino & 27 & 26 & $\begin{array}{c}\text { Publicidade e } \\
\text { Propaganda }\end{array}$ \\
\hline E & $50-60$ & Masculino & 35 & 25 & $\begin{array}{c}\text { Publicidade e } \\
\text { Propaganda incompleto }\end{array}$ \\
\hline
\end{tabular}

Nota: No intuito de preservar as identidades dos executivos e das suas respectivas agências, uma letra foi atribuída de forma aleatória a cada entrevistado, os quais de ora em diante passarão a ser identificados pelas letras " $A$ ", " $B$ ", "C", " $D$ " e "E".

Fonte: Dados da Pesquisa.

Os dados acima demonstram que a faixa etária dos entrevistados os coloca entre 30 e 60 anos de idade, tendo, em média, considerável experiência no mercado publicitário, cujas criações das respectivas agências publicitárias ocorrido há 28 anos em média, ou seja, entre o início e o final dos anos de 1980. A formação de cada entrevistado está por sua vez condizente com a área de atividade e a profissão escolhida pelos participantes da pesquisa. Destes, quatro são do sexo masculino e apenas um do sexo feminino.

A seguir, aparecem os mapas articulando, no decurso do processo, as três categorias centrais da pesquisa: a) a ética na vida pessoal e profissional; b) o anunciante, a agência de publicidade e propaganda e o consumidor/sociedade; e, por fim, c) os instrumentos de regulamentação no âmbito da atividade publicitária.

\section{A Ética na Vida Pessoal e Profissional}

O processo interpretativo fez aflorar um sentido ou uma concepção de ética que aponta para a existência de um vínculo efetivo entre essas duas esferas da existência humana: a vida pessoal e a vida profissional do entrevistado. Abaixo, as principais afirmações dos entrevistados sobre o tema.

Tabela 2

Ética na Vida Pessoal e Profissional

\begin{tabular}{|c|l|}
\hline Entrevistado & \multicolumn{1}{c|}{ Concepção de Ética } \\
\hline A & $\begin{array}{l}\text { “Eu entendo por ética todo o relacionamento que preserva os bons princípios e a inter-relação } \\
\text { entre as pessoas e as suas atividades dentro da norma e da lei. O respeito, principalmente, à } \\
\text { pessoa humana." (grifos nossos) }\end{array}$ \\
\hline B & $\begin{array}{l}\text { "Ética é o conjunto de valores que norteiam uma pessoa. Como falava Hobbes: 'O homem é o } \\
\text { lobo do próprio homem'; a ética - os valores, toda essa base - é que faz com que o homem não } \\
\text { transgrida certas regras básicas, que acaba te impedindo de ser um animal, que te torna } \\
\text { 'alguém com penso'. Acho-a 'super' importante." (grifos nossos) }\end{array}$ \\
\hline
\end{tabular}




\begin{tabular}{|c|l|}
\hline C & $\begin{array}{l}\text { "A ética, a gente ser ético é não agir de maneira que contrarie pensamentos e valores seus. } \\
\text { Valores que se adquiriu, que trouxe de casa; ações e atitudes que não contrariem esse teu } \\
\text { elenco de valores é agir eticamente. Obviamente que a ética tem muito a ver com qual grupo } \\
\text { social se está envolvido. Determinados valores éticos mudam de sociedade pra sociedade ou de } \\
\text { comunidade pra comunidade." (grifos nossos) }\end{array}$ \\
\hline D & $\begin{array}{l}\text { "Eu acho que ética é a prática de um conjunto de valores (...) Tuas atitudes frente a um } \\
\text { conjunto de valores. Esses valores são próprios, mas são evidentemente valores construídos } \\
\text { pelo mundo que te cerca. E certos ou errados, eles são frutos dessa construção social. Então } \\
\text { adequar uma conduta a esse conjunto de valores me parece ter o referencial ético do momento } \\
\text { e da tua atitude. O que ele tem de valores e o que o mercado ou a sociedade acreditam que são } \\
\text { valores corretos, valores que um bom profissional deva perseguir. Então é essa a lógica. (...) são } \\
\text { evidentemente valores construídos pelo mundo que te cerca." (grifos nossos) }\end{array}$ \\
\hline E & $\begin{array}{l}\text { "Ética por isso, é um conjunto de valores pessoais, que a gente traz no seio familiar. Muitas } \\
\text { vezes a gente tem que, no nosso conjunto que a gente traz e que vamos aprimorando, } \\
\text { evoluindo, ele se choca, em alguns momentos, com a nossa atividade, com o relacionamento da } \\
\text { nossa atividade, no relacionamento de negócios, com a comunidade publicitária, ou seja, várias } \\
\text { esferas que a gente tem que se relacionar. (...) então muitas vezes não há a total concordância } \\
\text { entre os nossos valores com os que a gente vai encontrando na vida. Então a gente tem que } \\
\text { lutar pra impor os nossos valores, fazer valer os nossos valores e tal." (grifos nossos) }\end{array}$ \\
\hline
\end{tabular}

Nota: Devido a limitações no tamanho do artigo, alguns diálogos não puderam ser integralmente transcritos na tabela da seção respectiva.

Fonte: Dados da Pesquisa.

Ao iniciar as entrevistas foi solicitado aos participantes que se manifestassem sobre o que eles entendiam por ética. Três deles, os entrevistados "A, B e E", a definem como sendo "a prática de um conjunto de valores pessoais adquiridos ou fruto de uma construção social" presente nas relações interpessoais, seja na família, com a comunidade publicitária e a sociedade em geral. É o caso do entrevistado "B" para quem a "ética é o conjunto de valores que norteiam uma pessoa"; e dos entrevistados "E", que define a "ética [como] um conjunto de valores pessoais, que a gente traz no "seio familiar", com o intuito de, ratifica o entrevistado "A", "preservar os bons princípios e a inter-relação entre as pessoas".

Já os entrevistados "C e D" vinculam sua concepção de ética ou sistema de valoração ao contexto social, ou seja, a determinações externas, posicionamento verificável na Tabela 2: “(...) a ética tem muito a ver com qual grupo social se está envolvido, muda[ndo] de sociedade pra sociedade ou de comunidade pra comunidade" (Entrevistado "C"). O entrevistado "D" corrobora esta ideia afirmando que os "valores [são] construídos pelo mundo que te cerca, e certos ou errados, eles são fruto dessa construção". Ou seja, são valores próprios de um indivíduo, mas construídos socialmente segundo esta lógica, quer dizer, "valores que um profissional deve seguir". É interessante observar, também, que o entrevistado "D"coloca a ética como sendo uma atitude frente a um conjunto de valores vinculados à atividade profissional, devendo, de acordo com o momento, adequar-se a ele.

$\mathrm{Na}$ visão do entrevistado "E", "a gente tem que lutar pra impor os nossos valores, fazer valer os nossos valores e tal". Isto evidencia uma situação de tensão entre a ordem dos valores que um profissional exposa, as demandas valorativas dominantes em determinado setor de atividade, publicidade e propaganda neste caso, e destas com os valores éticos prevalentes em uma determinada comunidade ou sociedade. $\mathrm{O}$ respeito à lei e, sobretudo, diz o entrevistado "A", "o respeito principalmente à pessoa humana", configuram a dinâmica intersubjetiva presente nas escolhas éticas. O chamamento à afirmação de Thomas Hobbes, pelo 
entrevistado "B" - "o homem é o lobo do próprio homem" -, põe em evidência algo relevante para a tomada de decisões éticas: a capacidade humana racional. Na filosofia clássica, esta é a condição que permite ao homem distinguir o justo do injusto, o erro da mentira, o aceitável do inaceitável. É isto, em suma, que está dito pelo entrevistado "B": "A ética - como um conjunto de valores de base - é que faz com que o homem não transgrida certas regras básicas, que acaba te impedindo de ser um animal, que te torna 'alguém com penso". Com efeito, se o profissional de publicidade e propaganda transgredir certas regras ou princípios éticos, isso irá refletir-se na atuação da agência, posição ratificada pelo entrevistado "A": "Eu vejo, por exemplo, a falta de ética [das agências] pelo caráter de quem dirige as empresas, entende?"

Ademais, quando os executivos foram questionados sobre as possibilidades ou não de um agir profissional fundamentado na ética, as respostas e as justificativas apresentadas por eles foram bastante distintas. O entrevistado "A" diz que não se recorda de "ter tomado nenhuma atitude [que do seu ponto de vista comprometesse a] ética durante o exercício de [sua] profissão, de tal sorte que nunca perde[u] um cliente por ter feito uma campanha que causasse problema para algum grupo de pessoas ou de consumidores". Com isso, "a agência busca apresentar à sociedade a imagem de uma empresa ética".

O entrevistado "B" diz ter sido coagido, logo no início da sua carreira, a agir de forma eticamente inadequada, razão pela qual teria se desvinculado da antiga agência. Note-se do ponto de viste de gênero que, no universo da pesquisa, este foi o único representante do sexo feminino, não sendo casual, ao que parece, sua referência a Hobbes (rever Tabela 2).

O entrevistado "C" alega que a sua agência nunca foi denunciada ao CONAR ou a quaisquer outros órgãos de regulamentação, manifestação contradita pelos fatos, já que os entrevistadores estavam de posse de uma denúncia pública contra a respectiva agência. Mesmo assim, diante da apresentação, pelos entrevistadores, da materialidade da prova, o profissional negou o fato. Porém, algo distinto se passa com o entrevistado "D": o executivo assume publicamente que tomou decisões que romperam com os seus próprios valores éticos. Isto ocorreu, conforme refere, quando, em período eleitoral, ele passou a fazer campanhas políticas para candidatos de quem ele mesmo suspeitava de sua integridade ética. Sobre isto, declara: "Num determinado momento da história da agência nós fizemos uma campanha política e a minha ética pessoal me revelava que aquele candidato era um sem-vergonha, um ordinário, um podre. E nós estávamos fazendo uma campanha pra ele, contratado pra ele e ali eu tava realmente numa crise ética entre o pessoal e o profissional".

Por fim, o entrevistado "E" afirma que, quando foi confrontado com situações contraditórias, agiu da seguinte maneira: "[...] A gente foi convidado a abrir mão desse conjunto de valores que a gente defende. E em alguns dos casos a gente conseguiu trazer o cliente para esse respeito e alguns outros tivemos de abrir mão da nossa relação com aquele cliente. Mas a nossa conduta é sempre informar, educar o cliente, trazê-lo para esse meio, fazê-lo entender porque as coisas acontecem desse jeito".

Não obstante as manifestações acima, fica evidenciado que apenas um dentre eles, este é o caso do entrevistado "A", explicita ou dá um conteúdo efetivo ao que ele entende por [vida] ética: "[...] todo o relacionamento que preserva os bons princípios e a inter-relação entre as pessoas e as suas atividades dentro da norma e da lei. O respeito, principalmente, à pessoa humana". Assim, o respeito ao outro constitui o fundamento da prática ética, complementado pelo elemento externo que é o atendimento à norma e à lei, seja na relação com as pessoas ou na realização das suas atividades profissionais.

Nos casos dos entrevistados "C e D", ao vincularem a concepção de ética ou sistema de valoração ao caráter determinante das pressões sociais, no sentido de que o contexto inculca certas regras e preceitos, remete a uma perspectiva importante para a ética, posto que a prioridade é atribuída à formulação e definição de práticas por um mecanismo de adequação às pressões externas. O essencial, neste caso, não é o estudo dos códigos, como externalidade, mas compreender e definir como o sujeito se apropria da norma, preocupação típica, conforme visto acima, das abordagens deontológica e utilitarista da ética. Aqui, a pretensão consiste em realizar essa conexão entre como um indivíduo deve "praticar a honestidade, viver a sinceridade, ser justo, etc., em relação a uns princípios éticos ou a um código estabelecido" (RUIZ, 2004. p. 103), o que 
supõe, do ponto de vista das práticas, "singularizar com eficiência os universais éticos". Todavia, dessa interrelação entre a vida subjetiva e a vida social podem surgir tensões, caso as regras ou leis externas venham a se contrapor a interesses que os envolvidos não desejam renunciar ou a valores que estariam arraigados numa dimensão mais profunda da subjetividade (SILVA, 2010).

\section{O Anunciante, a Agência de Publicidade e Propaganda e o Consumidor/Sociedade}

A Tabela 3 tem por foco a categoria de análise que trata da relação entre o anunciante, a agência de publicidade e propaganda e o consumidor/sociedade.

Tabela 3

O Anunciante, a Agência de Publicidade e Propaganda e o Consumidor/Sociedade

\begin{tabular}{|c|c|}
\hline Entrevistado & Relação Anunciante x Agência x Consumidor \\
\hline \multirow[t]{2}{*}{ A } & $\begin{array}{l}\text { "Nós, por exemplo, que atuamos na atividade publicitária, nós estamos muito envolvidos na } \\
\text { ética, no respeito ao consumidor, aos seus desejos e as suas vontades, no respeito ao emissor } \\
\text { da mensagem que é o patrocinador da mensagem, no respeito aos nossos competidores na } \\
\text { atividade e no respeito, também, aos meios de comunicação. Claro que as mensagens aqui } \\
\text { concebidas e enviadas, elas precisam estar dentro da lei, da ética, do melhor relacionamento } \\
\text { entre os vários grupos." (grifos nossos) }\end{array}$ \\
\hline & $\begin{array}{l}\text { "Olha, eu sou um publicitário por convicção; assim, eu amo a minha atividade e acredito no } \\
\text { papel importantíssimo que ela [a agência] tem," }\end{array}$ \\
\hline \multirow{3}{*}{ B } & $\begin{array}{l}\text { “Há legislação que norteia a publicidade (percentual por comissão, como funciona, etc.), mas } \\
\text { muitas empresas fazem coisas 'por baixo do pano' no mercado. Colocam um 'preço A' e um } \\
\text { 'preço B', e isso - na Publicidade - é muito normal. Nossa empresa é vista como 'os caretas', 'os } \\
\text { cdf's' por não fazer essa 'jogatina'. Preço A, preço B não é nada mais do que propina, serviço } \\
\text { com gráficas sem nota, cobrar mais do cliente, fazer serviço só com algumas empresas e receber } \\
\text { por fora”. (grifos nossos) }\end{array}$ \\
\hline & $\begin{array}{l}\text { "[...] E isso é péssimo para o nome do publicitário, para o nome agência. 'Suja' toda uma } \\
\text { categoria, uma profissão." }\end{array}$ \\
\hline & $\begin{array}{l}\text { "Claro que há outras empresas que também agem de maneira ética no ramo, mas, na verdade, } \\
\text { não é o 'comum' do mercado, infelizmente". (grifos nossos) }\end{array}$ \\
\hline \multirow[b]{2}{*}{ C } & $\begin{array}{l}\text { "[...] uma comunicação não é somente o que eu digo, mas o que é percebido. Quer dizer, eu } \\
\text { disse uma frase e tu a percebeste em sentido contrário. O erro é meu, porque não fui muito } \\
\text { claro." }\end{array}$ \\
\hline & $\begin{array}{l}\text { "Obviamente tem um diálogo aí: pessoa com a empresa e empresa com a sociedade e a pessoa } \\
\text { com a sociedade conversam e esses valores podem ir se modificando com o passar do tempo. } \\
\text { Tem valores éticos de muitos anos atrás que eram muito importantes e que hoje em dia não } \\
\text { servem mais." }\end{array}$ \\
\hline
\end{tabular}




\begin{tabular}{|c|c|}
\hline \multirow{3}{*}{ D } & $\begin{array}{l}\text { "Vocês na vida de vocês compram produtos, a gente na vida da gente compra produtos, curte ou } \\
\text { não curte a experiência e se não curte, larga." }\end{array}$ \\
\hline & $\begin{array}{l}\text { "[...] porque não somos nós que estamos assinando o anúncio, não é a posição da agência, é a } \\
\text { posição de um cliente que através da agência tá assumindo publicamente." }\end{array}$ \\
\hline & $\begin{array}{l}\text { "[...] por isso que o Código de Defesa do Consumidor estabelece o anúncio no contrato cuja } \\
\text { grande responsabilidade é efetivamente do elemento anunciante. Nós somos, no máximo, co- } \\
\text { responsável por esse tipo de proposta. Na verdade essa crise ética do anúncio é } \\
\text { fundamentalmente do anunciante. À agencia cabe dar formas e tintas para que aquela } \\
\text { mensagem seja efetiva no target escolhida pelo cliente." (grifos nossos) }\end{array}$ \\
\hline \multirow{2}{*}{$E$} & $\begin{array}{l}\text { "Eu acho que a gente vive num país que a propaganda não é muitas vezes vista como uma } \\
\text { fiç̧ão, muitas vezes ela vista e percebida como realidade" }\end{array}$ \\
\hline & $\begin{array}{l}\text { "[...] A propaganda é confundida com informação. Então é fundamental que essa propaganda } \\
\text { seja feita conforme regras de comportamento.." }\end{array}$ \\
\hline
\end{tabular}

Nota: Devido a limitações no tamanho do artigo, alguns diálogos não puderam ser integralmente transcritos na tabela da seção respectiva.

Fonte: Dados da Pesquisa.

$\mathrm{Na}$ questão centrada na relação que se estabelece entre o consumidor, o anunciante e a agência de publicidade e propaganda é possível observar uma diversidade de opiniões, expressando, em alguns casos, posicionamentos contraditórios. Nesse sentido, o entrevistado "A" respondeu à questão dizendo que o respeito ao consumidor (aos seus desejos e às suas vontades), ao anunciante, aos competidores e aos meios de comunicação é a base para uma atuação ética. Nos seus termos, "A" integra uma agência que prima por sua imagem junto à sociedade e que sabe ou tem consciência da importância da propaganda. Para o entrevistado, o consumidor não é uma "esponja", porque possui o poder de escolha, sendo a facilitação de informação o papel da propaganda.

O entrevistado "B", por sua vez, analisa o mercado e as demais agências, e afirma estar ciente da postura equivocada de muitos de seus colegas. Por não se coadunar a uma prática que desconsidera a lei - falsear orçamentos - o que define como "jogatina", a sua empresa é tida como "os $c d f$ 's", já que, face à decisão de preservar seus padrões éticos, escolhe o seu nicho de atuação no mercado. Para ela, uma conduta equivocada pode comprometer não apenas a imagem da agência, como também o nome de toda uma categoria, de toda a profissão. Nesse processo, conforme declara "C": "Obviamente tem um diálogo aí: pessoa com a empresa e empresa com a sociedade e esses valores podem ir se modificando com o passar do tempo". Na visão deste, sempre que ocorrer um erro de comunicação, a culpa é do emissor da mensagem. Até porque, conforme reza o Capítulo 2, Artigo $4^{\circ}$ do Código de Defesa do Consumidor, passados 20 anos de sua promulgação, ele, o consumidor, é reconhecido como constituindo o lado vulnerável no mercado de consumo.

Porém, dentre os posicionamentos, o maior contraste remete às falas dos participantes "D" e "E"; "D" se posiciona como um expert, pretensamente neutro, posto que lhe cabe apenas tornar viável o interesse do anunciante. Para ele, conforme está dito, toda e qualquer responsabilidade sobre a veiculação da propaganda é do anunciante; o controle é assegurado pelo CONAR, "porque não somos nós que estamos assinando o anúncio: não é a posição da agência, é a posição de um cliente que através da agência tá assumindo 
publicamente. Nós somos, no máximo, coresponsável [...]. Essa crise de ética do anúncio é fundamentalmente do anunciante". Ao consumidor resta o papel, apenas, de escolha e de consumo do bem ou serviço ofertado pelo anunciante. Ora, nem o mediador, por seu vínculo de coresponsabilidade, reduz-se a uma mônada, nem o consumidor é alguém tão raso e pretensamente fadado a consumir o que lhe é meramente proposto pela mídia.

Não obstante alerta "E": “[...] a gente vive num país que a propaganda não é muitas vezes vista como uma ficção, muitas vezes ela é vista e percebida como realidade. [...] A propaganda é confundida com informação. Então é fundamental que essa propaganda seja feita conforme regras de comportamento". Com este posicionamento, o entrevistado chama a atenção para a necessidade de levar em consideração os possíveis impactos dessa atividade num país onde, segundo dados do IBGE de 2009, "um em cada cinco brasileiros é analfabeto funcional (20,3\% do total)", índice ao qual se somam os " 14,1 milhões de brasileiros $(9,7 \%$ da população) com analfabetismo total", alcançando o índice de $30 \%$ da população brasileira (BBC BRASIL, 2010).

No caso das demandas de anunciantes, entende o entrevistado " $\mathrm{C}$ " que existem algumas agências de publicidade e propaganda que optam por não atender determinados clientes, como por exemplo, de políticos e do Governo. Então: "Por que muita agência não quer atender conta política? Porque vem uma cenoura de corrupção. Tá numa concorrência e pra ganhá-la tem que molhar a mão de alguém [...]”. Porém afirma estar adotando uma certa medida de compatibilização: ele tem aceitado trabalhar em campanhas políticas, mas só as criam aqueles funcionários que acreditam na proposta do candidato em questão. Ao fazer isso, o entrevistado tenta demonstrar que é possível realizar campanhas políticas preservando valores éticos, pelo menos no que tange àqueles profissionais diretamente envolvidos na situação. Em suma, isto é possível, desde que sejam tomados certos cuidados. Contudo, absteve-se de responder a qual concepção de ética estava de fato se referindo, posicionamento que, em última instância, fica utilitariamente condicionado ao rumo dos acontecimentos. E, nisto, ele não se distancia o bastante da maioria dos executivos entrevistados.

\section{Os Instrumentos de Regulamentação em Publicidade e Propaganda}

Distintamente das anteriores, a Tabela 4 tem seu foco voltado à categoria que analisa a relação entre a agência de publicidade e propaganda e a regulamentação do setor de atividade.

Tabela 4

Comentários dos Entrevistados sobre a Regulamentação

\begin{tabular}{|c|l|l|}
\hline Entrevistado & \multicolumn{2}{|c|}{ Regulamentação } \\
\hline \multirow{3}{*}{ A } & \multirow{2}{*}{ Governo } & $\begin{array}{l}\text { "Eu sou muito contra a interferência do governo em qualquer atividade. E } \\
\text { acho o seguinte, isso e um contrassenso, pois ao mesmo tempo que ele } \\
\text { estimula que a empresa cresça, dê emprego e tal, ele tolhe a empresa no } \\
\text { sentido de divulgar aquilo que [ela] faz". (grifos nossos) }\end{array}$ \\
\cline { 2 - 3 } & $\begin{array}{l}\text { "Então, por que não permitir que a empresa produza cigarro, por exemplo, ao } \\
\text { invés de "cortar" que ela se comunique?" }\end{array}$ \\
\hline
\end{tabular}




\begin{tabular}{|c|c|c|}
\hline & & “Não deveria então, não permitir produzir?!” \\
\hline & & $\begin{array}{l}\text { "E se permite, se estimula que produza, porque não permitir [a] ela de se } \\
\text { comunicar, entende?" }\end{array}$ \\
\hline & CONAR & $\begin{array}{l}\text { "Então assim, eu acho que o mercado ficou extremamente competitivo e isso é } \\
\text { mais fácil para uma atitude não ética (...) a atividade se prostituiu, porque } \\
\text { cada um faz o seu preço." (grifos nossos) }\end{array}$ \\
\hline & & $\begin{array}{l}\text { “(...) acho que precisa isso, o mercado precisa de algum controle, entende. } \\
\text { Porque ele não se controla sozinho." }\end{array}$ \\
\hline & Código de Ética & $\begin{array}{l}\text { "Não. Nós temos assim, oh, uma filosofia. Nós temos princípios, visão e nós } \\
\text { temos normas de comportamento que são as nossas regras e todos sabem } \\
\text { disso." (grifos nossos) }\end{array}$ \\
\hline \multirow{3}{*}{ B } & Governo & Não foi questionado a respeito. \\
\hline & CONAR & Não foi questionado a respeito. \\
\hline & Código de Ética & $\begin{array}{l}\text { A empresa não possui Código de Ética, e em muitos casos ela acha isso uma } \\
\text { hipocrisia, pois muitas têm escrito e não o cumprem na prática. Eles não veem } \\
\text { a necessidade de implantação. }\end{array}$ \\
\hline \multirow{3}{*}{ C } & Governo & Não foi questionado a respeito. \\
\hline & CONAR & $\begin{array}{l}\text { "Acho que é um mecanismo, um órgão que funciona. Ele acata a denúncia de } \\
\text { alguém. Não é um órgão estatal. Ele não adota uma prática de censura prévia } \\
\text { como a gente já teve no Brasil." (grifos nossos) }\end{array}$ \\
\hline & Código de Ética & $\begin{array}{l}\text { "Nós já pensamos em ter um código de ética, mas nunca se implantou uma } \\
\text { coisa escrita, detalhada. Eu tenho um pouco de, muitas vezes, eu } \\
\text { particularmente tenho muita bronca com essa questão de burocracia, e vejo } \\
\text { muitas vezes que tem muita coisa escrita e não é praticada." }\end{array}$ \\
\hline \multirow{3}{*}{ D } & Governo & $\begin{array}{l}\text { "Outra questão importante: a quem interessa o cerceamento da atividade } \\
\text { publicitária? Fundamentalmente o grande interessado disso é o cara que é } \\
\text { líder de mercado (...) Esse cerceamento é absolutamente antidemocrático, à } \\
\text { medida em que ele enfraquece economicamente os mecanismos de } \\
\text { comunicação - visto a regulamentação." (grifos nossos) }\end{array}$ \\
\hline & CONAR & $\begin{array}{l}\text { "Eu acho o CONAR absolutamente fantástico, inédito, o exercício brilhante de } \\
\text { autorregulamentação, de autodisciplina, acho um exercício absolutamente } \\
\text { brilhante. E é uma iniciativa que vários países do mundo tentam copiar e não } \\
\text { conseguem construir uma relação tão boa quanto." (grifos nossos) }\end{array}$ \\
\hline & Código de Ética & $\begin{array}{l}\text { "A resposta mais sincera sobre implantar é não. Nós já redigimos para nossos } \\
\text { clientes uma série de códigos de ética, já fizemos } 10 \text { ou } 15 \text { para as mais } \\
\text { diferentes empresas e sempre verificamos essa prática como de muito valor." } \\
\text { (grifos nossos) }\end{array}$ \\
\hline
\end{tabular}




\begin{tabular}{|c|c|c|}
\hline \multirow{4}{*}{$\mathrm{E}$} & Governo & $\begin{array}{l}\text { "Apesar de que eu acho que quando há uma interferência promovida por } \\
\text { entidades que tem no governo, não no governo, mas apoio, respaldo no } \\
\text { Congresso, eu acho que são importantes. (...) eu acho importante porque é } \\
\text { uma manifestação da sociedade." (grifos nossos) }\end{array}$ \\
\hline & CONAR & $\begin{array}{l}\text { "Então acho que o CONAR tem um enorme papel e sou totalmente favorável } \\
\text { ao CONAR." (grifos nossos) }\end{array}$ \\
\hline & Código de Ética & $\begin{array}{l}\text { "Um código de ética escrito e padronizado não. Nós temos um conjunto de } \\
\text { valores nossos aí. Mas não temos um código de ética. Acho que nunca foi } \\
\text { preciso. (...) quer dizer, as pessoas se adaptam a esse padrão, com muito rigor." }\end{array}$ \\
\hline & Regulamentação & $\begin{array}{l}\text { "Eu acho que o Brasil não é maduro na sua convivência de empresas, com a } \\
\text { relação com consumidor, no exercício da cidadania, nos direitos do } \\
\text { consumidor, não é um país maduro. E eu acho que quanto mais proteção o } \\
\text { consumidor tiver, acho mais saudável e, de certa forma, purifica essas relações } \\
\text { e fazem com que elas sejam mais desenvolvidas e tal e que as empresas não } \\
\text { façam a bagunça que já fizeram de anunciar produtos, de fazer promessas } \\
\text { falsas". (grifos nossos) }\end{array}$ \\
\hline
\end{tabular}

Nota: Devido a limitações no tamanho do artigo, alguns diálogos não puderam ser integralmente transcritos na tabela da seção respectiva.

Fonte: Dados da Pesquisa.

Sobre esta questão envolvendo, mais particularmente, as ações do CONAR, do Governo e, ainda, a formas de regulação interna, no caso, o Código de Ética, as opiniões foram muito semelhantes, excetuando-se à do entrevistado "E" no que tange ao seu posicionamento com relação à do Governo. Para ele, "[...] o Brasil não é maduro na sua convivência de empresas, com a relação com consumidor, no exercício da cidadania, nos direitos do consumidor", já que fizeram "a bagunça de anunciar produtos, de fazer promessas falsas". Em nome disso, considera a proteção ao consumidor uma iniciativa saudável.

Sobre o CONAR, os entrevistados são unânimes em afirmar que se trata de um órgão exemplar, de extrema importância e com uma atuação louvável e sintetizada de forma correta nesta fala do entrevistado "A": "[...] eu acho que o mercado ficou extremamente competitivo e isso torna mais fácil a atitude não-ética [...] acho, portanto, que precisa isso, o mercado precisa de algum controle, entende? Porque ele não se controla sozinho". Mas ao se pronunciarem sobre possíveis intervenções do Governo na publicidade e propaganda, "A, B, C, e D" se posicionaram francamente contrários, pois "ao mesmo tempo em que [o Governo] estimula que a empresa cresça", diz o entrevistado " $A$ ", "ele tolhe a empresa de divulgar aquilo que ela faz". E prossegue: "E a quem essa intervenção beneficiaria? Se a intenção é coibir o uso, do cigarro por exemplo, por que não coibir a produção das mercadorias, ao invés de 'cortar' que ela se comunique?" De forma distinta, o entrevistado "E" apoia, além da regulação exercida pelo CONAR, aquelas provindas do Governo, respaldadas pelo Congresso, posto que representam uma manifestação da sociedade.

No que tange à formulação e adoção ou não de um Código de Ética próprio, os participantes responderam de forma unânime e taxativa: Não o adotam, e acreditam tratar-se, muitas vezes, de um recurso hipócrita (Entrevistado "B"), como também tende a reduzir-se a algo escrito, um mero padrão comportamental não cumprido na prática (Entrevistado "C"). Em vista disso, traduz "E", eles preferem deixar-se guiar pelos seus valores. O inusitado, neste caso, refere-se ao exposto pelo entrevistado "D": "A resposta mais sincera sobre implantar é não. Nós já redigimos para nossos clientes uma série de códigos de ética, já fizemos 10 ou 15 para as mais diferentes empresas [...]" O que se verifica, neste caso, é o surgimento do moralismo, ou 
melhor, da figura do "canalha moralizador" (COMPTE-SPONVILLE, 2005, p. 65). Quer dizer, é ele mesmo quem, logo acima, explicitamente remete ao anunciante a responsabilidade pela transgressão ética, isto é, "nós apenas assinamos [...]. A crise de ética do anúncio é do anunciante".

Nessa perspectiva, a manifestação do entrevistado "A" adquire, para o estudo, um significado peculiar. Diz ele: "Não [temos um código de ética]. Nós temos [...] uma filosofia. Nós temos princípios, visão e nós temos normas de comportamento que são as nossas regras e todos sabem disso". A existência de um referencial ético-normativo, conhecido por todos, torna viável a consecução de práticas compartilhadas, meio vital para o aperfeiçoamento da própria cultura organizacional. Essas condições abrem a possibilidade aos membros da organização de concretizar uma ação acompanhada de consciência moral, fundamento da responsabilidade moral, e aqui denominada de autenticidade. Seria este um posicionamento que desafia o índice obtido pelo Brasil na série histórica do ranking da corrupção no mundo, ocupando, na última avaliação, o lugar 69 na lista hoje constituída por 178 países? (TRANSPARENCY INTERNATIONAL, 2010). Mas, lembra Hernani Donato: "Verdade que ela, a corrupção, viceja onde haja relacionamento entre o que pode e o que deseja" GORZONI, 2010, p. 32).

\section{Conclusões}

O Brasil é uma das maiores economias do mundo no que se refere a investimento em mídia, passando, provavelmente, da oitava colocação, para a sexta colocação (PEREIRA e TURLÃ̃, 2010), com isso ultrapassando Itália e França e ficando atrás apenas de, pela ordem, Estados Unidos, Japão, China, Alemanha e Reino Unido. Aliado à disposição de investir no setor, há também o fato da propaganda estar sendo hoje vista como uma das formas de arte mais prolíferas de todos os tempos (SIMPSON, HORTON e BROWN, 1996), apresentando-se, por razões bastantes, como a ferramenta de marketing mais visível e mais exposta ao público (D’ANGELO, 2003). É notória portanto a relevância do estudo.

A falta de estudos sobre a relação entre escolhas éticas e atuação das agências de publicidade e propaganda no âmbito brasileiro e mundial é, nessa medida, um fato que surpreende, pois vivemos em uma sociedade democrática, e é comum e também visível a ocorrência de transgressões na esfera dos valores ou dos princípios éticos fundamentais. No cerne dessa análise, estão, portanto, as tensões, as decisões e as sensíveis dificuldades de ordem ética tal como as ressentem os executivos gaúchos que hoje labutam nas agências de comunicação pesquisadas.

A análise das práticas discursivas por meio da técnica do mapa de associação de ideias aponta, em última instância, para a existência de contradições entre o conteúdo dos posicionamentos éticos tal como se instituem nas práticas discursivas, aqui entendidas como práticas sociais, e a sua realização nos espaços de comunicação mediados pelas agências de publicidade e propaganda abrangidas pelo estudo. A atenção, neste caso, volta-se para os valores ou princípios a que fazem apelo ao concretizar essa mediação em uma tríplice perspectiva: o profissional da agência de publicidade e propaganda, os anunciantes e a sociedade em geral.

Dentre as principais constatações verifica-se a impossibilidade, para os entrevistados, de desvincular ou dissociar os referenciais éticos assumidos na esfera profissional daquele "conjunto de valores pessoais, que a gente traz no seio familiar" (Entrevistado "E"). Por serem indissociáveis, os valores assumidos na vida pessoal e na vida profissional impregnam, transpassam os modos de atuação de uma agência, desde aspectos concernentes à política de preços, passando pela valorização dos funcionários, até a aceitação ou não de propinas e sonegações de parte dos anunciantes ou quaisquer outros interessados que pretendam se utilizar da mídia para o alcance de objetivos que lhes são próprios. Esta afirmação assumida aqui de forma generalizada, ilustra, com bastante clareza, o exposto: "Eu vejo, por exemplo, a falta de ética pelo caráter de quem dirige as empresas, entende? Pelos objetivos que ele tem na vida" (Entrevistado "D"). Outro executivo, o entrevistado "C", ilustra o exposto: "A pessoa tem a sua ética e acho que não deve abrir mão dela". Porém, avança em seu discurso afirmando que sua agência não abre mão de oportunidades quando estas aparecem, 
mesmo que isto o coloque em contradição em virtude de razões éticas. "Eu posso atender um cliente que tem valores completamente diferentes dos meus", conclui então. Há consoante ao exposto, uma ênfase na perspectiva definida acima como a "ética dos comportamentos", uma preocupação típica das abordagens deontológica e utilitarista da ética, em suma, uma prática destinada a "singularizar com eficiência os universais éticos" (RUIZ, 2004, p. 104).

Não obstante, para alguns, concessões dessa natureza são afirmativamente como inaceitáveis, podendo levar ao rompimento da relação de serviço. Este é o caso do entrevistado "C", cujas ocorrências levaram-no a sustar a relação agência-anunciante, sendo esta a sua justificativa: "o procedimento [do cliente] altamente condenável, chegou a um ponto onde dissemos que não queríamos trabalhar mais pra eles e se rompeu isso". Para este executivo, "a idônea atuação profissional é uma contribuição que a sociedade tem direito a esperar de nós. E o que colhemos amanhã não é nada mais o fruto do que nós semeamos hoje”. Na perspectiva ética do entrevistado, quem vive no imediatismo, buscando méritos no curto prazo, é evidente, em qualquer âmbito - pessoal ou profissional - está fadado ao fracasso.

Outro aspecto a destacar é a ocorrência de certo "vazio ético", na medida em que apenas um dentre estes, o entrevistado "A", especifica o fundamento objetivo da sua concepção ética, bem como as consequências deste para a relação com o outro. Ao dizer que a ética é isto que preserva os bons princípios e a inter-relação entre as pessoas, ele distingue simultaneamente dois planos: enquanto na atividade profissional a conduta ética requer a observância da norma e da lei, no plano das relações, é o respeito, principalmente, à pessoa humana, aquilo a que originariamente a ética visa. Ele reconhece, portanto, que a vida ética não se limita nem aos códigos, nem a um agir ético calcado no dever. Nos termos aqui propostos, na vida ética, a alteridade, como fundamento originário da relação humana, é o critério ético a partir do qual deve pautar-se toda prática humana. "Este dever se constitui como tal pelo fato de que a alteridade é um referente intransponível além do qual só existe a (auto)destruição do mundo, da vida, do outro e como consequência o aniquilamento paulatino do sujeito" (RUIZ, 2004, p. 152). Aliás, é ele mesmo quem diz que "o mercado precisa de controle porque ele não se controla sozinho".

Desse ponto de vista, é igualmente relevante observar que, nenhum deles cogita ou manifesta interesse em formular um "código de ética" para a agência. Manifestam, com isso, seu descrédito quanto à possibilidade, neste setor de atividade, de fazer valer as normativas presentes nos códigos, tão bem intencionadas quanto possam ser as suas determinações. A ausência dessa formalidade torna ainda mais relevante a já declarada impossibilidade de desarticular, em termos de valores e princípios, vida ética no trabalho e na vida ética fora do trabalho. Simultaneamente, fica patente a importância atribuída pelos mesmos à atividade realizada pelos órgãos de regulamentação, a exemplo do CONAR, cuja intervenção é reconhecida como um meio capaz de evitar abusos face à acirrada competição do mercado. Isso justifica, é bem possível, a ausência de diretrizes internas formalmente estabelecidas sobre como deveriam se conduzir os profissionais da área da comunicação, ordenamento remete a outro dilema: a prioridade atribuída a um regramento formal, como é o caso do CONAR, sem uma referenciação explícita, no âmbito da agência, ao sistema de valoração do mundo que orienta a atuação do executivo, viria favorecer o selamento de compromissos segundo cânones próprios a essa área de atuação? Qualificadamente translúcido, pode-se dizer, é o uso retórico de argumentos, deixando evidente uma clara ruptura entre conceitos, ou melhor, frases prontas e a conduta profissional no cenário investigado. Tal fato pode ser observado na imprecisão de certas manifestações, bem como na ausência de conteúdo explícito sobre o significado real do próprio termo "ética" conformemente acima enunciado.

A conexão entre as três categorias de análise revela, contudo, imprecisões e ambiguidades, tornando-se imprópria qualquer generalização sobre o conteúdo da relação mantida pelas agências de publicidade e propaganda com a sociedade em geral no contexto em estudo. Nota-se, entretanto, que houve a partir dos anos 1950 uma significativa e crescente valorização do papel da ética nos negócios: primeiramente nos Estados Unidos e, depois, na Europa e no restante do mundo. Apesar de este movimento ter adquirido força após a ocorrência de alguns escândalos de corrupção, a ética não se reduz à correção de fenômenos deste tipo, nem perde sua importância quando estes diminuem ou desaparecem. Pois a ética impõe um rosto; 
porquanto, "[...] qualquer prática humana tem como limite a dignidade do outro, o respeito pela vida e a preservação do mundo" (RUIZ, 2004, p. 154). Assim sendo, na ética, nem todos os meios são justificáveis, mas tão somente aqueles que são consoantes aos fins da própria ação, e este fim é a nossa humanidade. Ou seja, "fins éticos exigem meios éticos" (CHAUI, 2004, p. 310).

Deste modo, o fato da propaganda brasileira ser reconhecida como uma das mais criativas do mundo, defende-se que não existe incompatibilidade ente ser inventivo e engenhoso, com a vivência do valor ético acima indicado: "o respeito, principalmente, à pessoa humana", sem excluir ao atendimento à norma e à lei, evitando com isso a licenciosidade. Compete também à sociedade organizar-se para viver e fazer valer esse princípio, ao que intervém, mais uma vez, o jornalista e escritor Hernani Donato: "[...] é verdade que ela, a corrupção, viceja onde haja relacionamento entre o que pode e o que deseja" (GORZONI, 2010, p. 32). Esse desafio, baseado na responsabilidade e na formação da consciência dos cidadãos, dirige-se tanto aos publicitários e profissionais dos meios de comunicação, quanto ao governo, instituições educacionais, às famílias e a cada um de nós, por meio do exercício de uma liberdade consciente e responsável. Tal como nos diz Étienne de la Boétie [1548] (2006): ser livre supõe educar-se para tal; cada um tem que conquistar a capacidade de construir a própria maneira de ser livre porém.

Dentre as limitações do estudo, o alcance dos resultados, ficando estes delimitados ao universo da pesquisa. Quanto ao número efetivo de entrevistas, isto é, cinco, torna-se factível aos objetivos do estudo, por duas principais razões: i) a existência de oligopolização no setor pesquisado, ou seja, é seleto o grupo de agências de comunicação bem-sucedidas na Região Metropolitana de Porto Alegre/RS; ii) atinente ao critério da pesquisa, o número de entrevistas realizadas abarca a totalidade das agências de publicidade e propaganda implicadas no estudo, conferindo aos dados a imprescindível representatividade.

O estudo também aponta para outras continuidades possíveis. Nesse sentido, sugere-se a realização de pesquisas com o objetivo de melhor compreender a repercussão do posicionamento ético embutido em propagandas veiculadas no território brasileiro comparando, inclusive, o desempenho das agências do ponto de vista financeiro. Também merece aprofundamento da questão relativa a gênero. Ora, no grupo de executivos havia não apenas uma única representante do sexo feminino: dentre todos, somente ela declara ter sido coagida, logo no início da sua carreira, a ceder em suas convicções éticas, motivo que a fez desvincularse da antiga agência. Outro possível foco, mais orientado para o mercado, consistiria, por fim, em verificar o quanto o cliente percebe e valoriza o caráter ético das agências de publicidade e propaganda, e o quanto isto repercute em termos de legitimidade social e empresarial e, porque não, na sua perenização.

Cabe reafirmar, desde o íntimo desta proposta, que a constituição do sujeito, desde o lócus da alteridade, se faz através da prática ética, e esta prática não só possui uma relação de exterioridade a respeito de um determinado código, seja interno ou externo; ela tem implicação na forma de ser do próprio sujeito. Assim, ao compartilhar significados, o sujeito afirma sua singularidade, ele se cria e se constitui de forma única e irrepeível pela interação criativa, dialógica com o mundo. Nesta recriação, o mundo e as circunstâncias existem de forma concreta e, nele, valor e sentido se imbricam, anunciando esta possibilidade humana essencial: ao valorar, todos nós (res)sentimos a nossa existência e o mundo em que atuamos. Recriar é renascer, abertos responsavelmente à interpelação do outro. E por ética, desse ponto de vista, entende-se, em essência, construir o sentido da vida humana desde o encontro com o outro.

\section{Referências}

AGRAWAL, J.; KAMAKURA, W. A. The economic worth of celebrity endorsers: An event study analysis. Journal of Marketing, v. 59, n. 3, p. 56-62, 1995.

ALDEN, D. L.; HOYER, W. D.; LEE, C. Identifying global and culture-specific dimensions of humor. Journal of Marketing, v. 57, n. 2, p. 64-75, 1993. 
ARISTÓTELES. Ética a Nicômacos. 4 Ed. Brasília: Editora da Universidade de Brasília, 2001.

ARRUDA, M. C. C. de; WhITAKER, M. do C.; RAMOS, J. M. R. R. Fundamentos da ética empresarial e econômica. São Paulo: Atlas, 2001.

BARBER, B. Há uma infantilização da relação com as mercadorias. Disponível em: <http://www.ihu.unisinos.br/index.php?option=com_noticias\&Itemid=18\&task=detalhe\&id=30708>. Acessado em $16 / 03 / 2010$.

BARTELS, R. The Identity Crisis in Marketing. Marketing Notes and Communications, v. 38, n. 4, p.73-76, 1974.

BBC BRASIL. Um em cada cinco brasileiros é analfabeto funcional, diz IBGE. Disponível em: <http://www.bbc.co.uk/portuguese/noticias/2010/09/100908_pnad_analfabetismo.shtml>. Acessado em 25/11/2010.

BOONE, L.; KURTZ, D. Marketing contemporâneo. 8. Ed. Rio de Janeiro: LTC, 1998.

BREGANTINI, D. Ética em tempos de crise. Revista Cult, v. 13, n 154, p. 45-46, 2010.

BRUNEL, F. F.; NELSON, M. R. Explaining gendered responses to "help-self" and "help-others" charity ad appeals: The mediating role of world-views. Journal of Advertising, v. 29, n. 3, p. 15-28, 2000.

BRUNER, G. C. Music, mood and marketing. Journal of Marketing, v. 54, n. 4, p. 94-104, 1990.

CHANDY, R. K.; TELLIS, G. J.; MACINNIS, D. J.; THAIVANICH, P. What to say when: Advertising appeals in evolving markets. Journal of Marketing Research, v. 38, n. 4, p. 399-414, 2001.

CHAUI, M. Convite à filosofia. 14 ed. São Paulo: Ática, 2004.

CHURCHILL Jr, G.; PETER, J. Paul. Marketing: Criando valor para o cliente. São Paulo: Saraiva, 2000.

CÓDIGO DE DEFESA DO CONSUMIDOR, 11/09/1990. Disponível em: <http://www.planalto.gov.br/ccivil/LEIS/L8078.htm>. Acessado em 05/04/2010.

CÓDIGO DE ÉTICA DOS PROFISSIONAIS DA PROPAGANDA, 10/1957. Disponível em <http://www.cenp.com.br/dd03pp.html >. Acessado em 05/04/2010.

COMPTE-SPONVILLE, A. O capitalismo é moral? São Paulo: Martins Fontes, 2005.

CONAR. Disponível em: 〈http://www.conar.com.br〉. Acessado em 25/03/2010.

CONSTITUIÇÃO DA REPÚBLICA FEDERATIVA DO BRASIL DE 1988. Disponível em: <http://www.planalto.gov.br/ccivil_03/constituicao/constitui\%C3\%A7ao.htm>. Acessado em 05/04/2010.

D`ANGELO, A. C. A ética no marketing, Revista de Administração Contemporânea, v. 7, n. 4, p. 55-75, 2003.

DICTIONNAIRE LE PETIT ROBERT. Paris: Le Robert, 1993.

DI LORENZO, W. G. O que é o bem comum? Jornal Estado de Direito, v. 4, n 26, 2010.

DRUMWRIGHT, M. E. Company advertising with a social dimension: The role of noneconomic criteria. Journal of Marketing, v. 60, n. 4, p. 71-87, 1996.

DRUMWRIGHT, M. E.; MURPHY, P. E. How advertising practitioners view ethics: Moral muteness, moral myopia, and moral imagination. Journal of Advertising, v. 33, n. 2, p. 7-24, 2004.

EL-ANSARY, A.; KRAMER Jr, O. E. Social marketing: The family planning experience. Journal of Marketing, v. 37, n. 3, p. 1-7, 1973.

FREIRE, Paulo. Entrevista cedida para Globo News, em 30 de março de 1997.

FREITAG, B. Itinerários de Antígona: A questão da moralidade. $3^{\text {a }}$ ed. Campinas/SP: Papirus, 2002. 
FONSECA, C. M. A ética. Textos Selecionados/Aristóteles. $2^{\mathrm{a}}$ ed. Bauru: EDIPRO, 2003.

GORZONI, P. Quando tudo acaba em pizza: os meandros da corrupção no Brasil e como este mal está instalado na sociedade. Revista Sociologia - Ciência \& Vida, n. 28, p. 26-33, 2010.

HENTHORNE, T. L.; LATOUR, M. S. A model to explore the ethics of erotic stimuli in print advertising, Journal of Business Ethics, v. 14, n. 7, p. 561-569, 1995.

HUTTON, J. G. The feel-good Society: How the "customer" metaphor is undermining american education, religion, media and healthcare. New Jersey: Pentagram Publishing, 2005.

IBOPE. Disponível em: 〈http://www.ibope.com.br〉. Acessado em 20/12/2008.

JONAS, H. Le principe responsabilité. Paris: Flammarion, 1995.

KAMLOT, D.; ROCHA, A. L. P. Humor na propaganda: Recall, atitude e afeição. In: ENCONTRO NACIONAL DOS PROGRAMAS DE PÓS-GRADUAÇÃO EM ADMINISTRAÇÃO - ENANPAD, 25. Anais... Campinas: São Paulo, 2001.

KELLARIS, J. J.; COX, A. D.; COX, D. The effect of background music on ad processing. Journal of Marketing, v. 57, n. 4, p. 114-125, 1993.

LA BOÉTIE, Étienne de [1548]. Discurso de la servidumbre voluntaria. Buenos Aires: SuperabundansHaut, 2006.

LATOUR, M. S.; HENTHORNE, T. L. Ethical judgments of sexual appeals in print advertising. Journal of Advertising, v. 23, n. 3, p. 81-91, 1994.

MAES, J. D.; JEFFERY, A.; SMITH, T. V. The American Association of Advertising Agencies (4As) standards of practice: How far does these Professional Association's Code of Ethics influence reach?, Journal of Business Ethics, v. 17, n. 11, p. 1155-1561, 1998.

M\&M Online. Disponível em: <http://www.mmonline.com.br>. Acessado em 10/04/2010.

NAIRN, A.; BERTHON, P. Creating the customer: The influence of advertising on consumer market segments evidence and ethics, Journal of Business Ethics, v. 42, n. 1, p. 83-99, 2003.

NEWELL, S.; GOLDSMITH, R. E.; BANZHAF, E. J. The effect of misleading environmental claims on consumer perceptions of advertisements. Journal of Marketing Theory and Practice, v. 6, n. 2, p. 48-60, 1998.

PEREIRA, E.; TURLÃO, F. Brasil fechará 2010 como $6^{\circ}$ maior da mídia mundial. M\&M Online, 31/03/2010. Disponível em: <http://www.mmonline.com.br>. Acessado em 10/04/2010.

PETERSON, R. T. The depiction of african american children's activities in television commercials: An assessment. Journal of Business Ethics, v. 36, p. 303-313, Apr.2002.

PETROLL, M. M.; LOVISON, A. M. Ética na propaganda: Confrontando tendências e perspectivas. In: Congresso Latino-Americano de Escolas de Administração - CLADEA, XL. Anais... Santiago: Chile, 2005.

PETROLL, M. M.; ROSSI, C. A. V. Apelo sexual na propaganda e seus efeitos sobre o consumidor: Um experimento em mídia impressa. RAUSP-e, v. 1, n. 2, p. 1-22, 2008.

PHILLIPS, B. J. In defense of Advertising: a social perspective. Journal of Business Ethics, v.16, n. 2, p.109-118, 1997.

PINHEIRO, O. G. Entrevista: Uma prática discursiva. In: SPINK, M. J. (org.). Práticas discursivas e produção de sentidos no cotidiano: aproximações teórico-metodológicas. $3^{\text {a }}$ ed. São Paulo: Cortez, 2004, p. 183-214.

RABAÇA, C. A.; BARBOSA, G. Dicionário de comunicação. São Paulo: Editora Ática, 1987.

REICHERT, T. Sex in advertising research: A review of content, effects, and functions of sexual information in consumer advertising. Annual Review of Sex Research, v. 13, p. 241-273, 2002. 
REVISTA EXAME, Os Dilemas da Ética, Ano 37, Edição 792, nº10, p.35-43, 14 de Maio de 2003.

RUIZ, C. M. M. B. A ética como prática de subjetivação: esboço de uma ética e estética da alteridade. In: PIVATTO, P. (Org.) Ética: Crise \& Perspectivas. Porto Alegre: EDIPUCRS, 2004, p. 95-163.

SÁNCHEZ VÁZQUEZ, Adolfo S. Ética. 26ª ed. Rio de Janeiro: Civilização Brasileira, 2005.

SCHUHWERK, M. E.; LEFKOFF-HAGIUS, R. Green or non-green? Does type of appeal matter when advertising a green product? Journal of Advertising, v. 24, n. 2, p. 45-54, 1995.

SCHWEIG, S. A evolução da propaganda na mídia impressa 1950-2000. Monografia de Graduação, Universidade do Vale do Rio dos Sinos, São Leopoldo, RS, Brasil, 2002.

SHIMP, T. A. Propaganda e promoção: Aspectos complementares da comunicação integrada de marketing. Porto Alegre: Bookman, 2002.

SILVA, F. L. Ética e situações-limite. Revista Cult, v. 13, n. 154, p. 45-46, 2010.

SIMPSON, P. M.; HORTON, S.; BROWN, G. Male nudity in advertisements: A modified replication and extension of gender and product effects. Academy of Marketing Science Journal, v. 24, n. 3, p. 257-262, 1996.

SOUZA, R. T. Ética como fundamento: Uma introdução à ética contemporânea. São Leopoldo: Nova Harmonia, 2004.

SPINK, M. J.; FREZZA, R.M.. Práticas Discursivas e produção de sentido: a perspectiva da Psicologia Social. In: SPINK, M. J. (org.). Práticas discursivas e produção de sentidos no cotidiano: aproximações teóricometodológicas. $3^{\text {a }}$ ed. São Paulo: Cortez, 2004, p. 17-39.

SPINK, M. J.; MEDRADO, B. Produção de sentidos no cotidiano: uma abordagem teórico-metodológica para análise das práticas discursivas. In: SPINK, M. J. (org.). Práticas discursivas e produção de sentidos no cotidiano: aproximações teórico-metodológicas. $3^{\mathrm{a}}$ ed. São Paulo: Cortez, 2004, p. 41-61.

TRANSPARENCY INTERNATIONAL. Disponível em: <http://www.transparency.org/policy_research/surveys_indices/cpi/2010/results>. Acessado em 08/11/2010.

O CONAR - Conselho Brasileiro de Autorregulamentação Publicitária - surgiu em 1980 com o intuito de regulamentar o conteúdo das campanhas publicitárias, através do Código de Ética da Propaganda, evitando, dessa maneira, que agentes externos a esse mercado, inclusive o Governo, viessem a assumir tal iniciativa. 